Tree diversity and above-ground carbon stock estimation in various land use systems in Banjarnegara, Banyumas and Purbalingga, Central Java 



\section{Tree diversity and Above-ground carbon Stock Estimation in various land use systems of Banjarnegara, Banyumas and Purbalingga, Central Java}

Subekti Rahayu and Sidiq Pambudi 


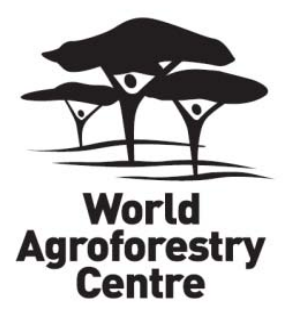

\section{Correct citation}

Rahayu S and Pambudi S. 2017. Tree diversity and Above-ground carbon Stock Estimation in various land use systems of Banjarnegara, Banyumas and Purbalingga, Central Java. Working Paper 271. Bogor, Indonesia: World Agroforestry Centre (ICRAF) Southeast Asia Regional Program. DOI: http://dx.doi.org/10.5716/WP17363.PDF

Titles in the Working Paper series aim to disseminate interim results on agroforestry research and practices, and stimulate feedback from the scientific community. Other publication series from the World Agroforestry Centre include Technical Manuals, Occasional Papers and the Trees for Change Series.

Published by the World Agroforestry Centre

Southeast Asia Regional Program

JL. CIFOR, Situ Gede, Sindang Barang, Bogor 16680

PO Box 161, Bogor 16001, Indonesia

Tel: +62 2518625415

Fax: +62 2518625416

Email: icraf-indonesia@cgiar.org

ICRAF Southeast Asia website: http://www.worldagroforestry.org/region/southeast-asia/

(C) World Agroforestry Centre 2017

Working paper no. 271

Photos/illustrations: the authors

\section{Disclaimer and copyright}

The views expressed in this publication are those of the author(s) and not necessarily those of the World Agroforestry Centre.

Articles appearing in this publication may be quoted or reproduced without charge, provided the source is acknowledged.

All images remain the sole property of their source and may not be used for any purpose without written permission of the source. 


\section{About the authors}

Subekti Rahayu is a biodiversity and carbon stock specialist at the World Agroforestry Centre. Her main areas of interest include biodiversity conservation, forest and landscape restoration, forest ecology, bioindicators and agroforestry ecology. She is a $\mathrm{PhD}$ candidate on restoration model in Samboja Research Forest, East Kalimantan. She has a master degree in Tropical Biodiversity Conservation from Bogor Agriculture University. She holds a bachelor degree from the same university, majoring in Plant Protection. She has had experience with carbon-stock measurement at plot level since 1998 and delivering training on the subject to various institutions in Indonesia and to local communities in Indonesia and Viet Nam since 2002. Contact: s.rahayu@ @ cgiar.org.

Sidiq Pambudi is research assistant in World Agroforestry Centre Indonesia. His areas of work generally on biodiversity assessment in various land use including analysis vegetation and aboveground carbon stock estimation. Aside from working on field work surveys, analyzing and interpreting data, he has also conducts trainings, and develops reports and briefs. Sidiq also passionate in wildlife study and experienced in conducting fauna inventory in various activity before joining World Agroforestry Centre. He received bachelor degree in Biology from Institut Teknologi Bandung in 2012, focusing on ecology and biosystematics research group. Contact: s.pambudi@cgiar.org 


\section{Abstract}

The loss of biodiversity and biomass due to economic reasons has a high impact on the environmental services provided by landscapes as well as on landscape sustainability. Ideally, sustainable development can be achieved through increasing income while environmental conditions are well managed and even improved. There is a long history of plantations of resin, timber and perennial crops in Banjarnegara, Banyumas and Purbalingga districts. However, expansion of monocultures such as annual crops of vegetables has occurred at higher elevations designated as protected areas. Increasing the carbon stock and tree species diversity is an option to improve environmental conditions. In total, 75 plots $(20 \times 100 \mathrm{~m})$ in 16 land use systems in Banyumas, Banjarnegara and Purbalingga were established to analyze the tree species composition and carbon stock content in each system. Low intensive management of complex agroforestry systems managed by smallholders contained a more diverse species range in all growth stages, but there were a more diverse range under medium-to-high intensive management by companies only in the seedling stage. Weeding activities direct impacted on naturally regenerating species in systems. Complex agroforest and slowgrowing, timber-based agroforest contained $60 \%$ of the carbon stock in undisturbed forest and simple crop-based agroforest and fast-growing timber-based systems that in turn contained about $25 \%$ of the carbon stock of undisturbed forest.

\section{Keywords:}

carbon stock, Central Java, sustainable development, tree diversity 


\section{Content}

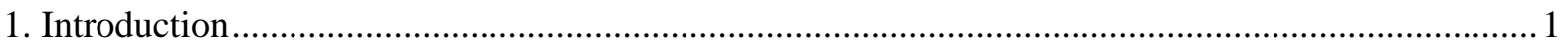

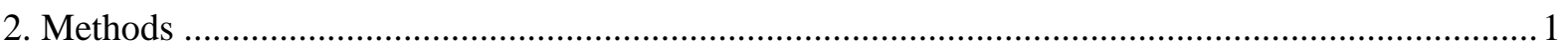

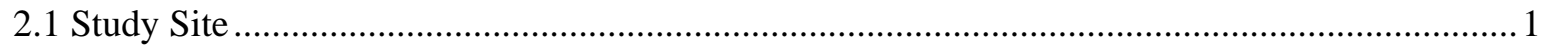

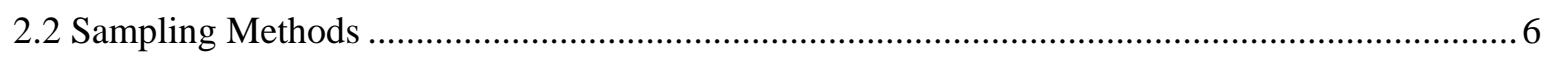

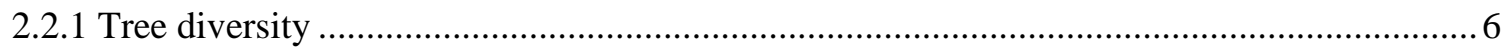

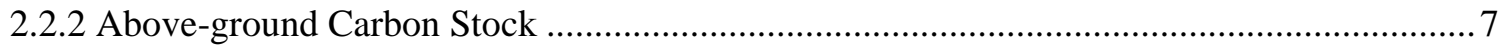

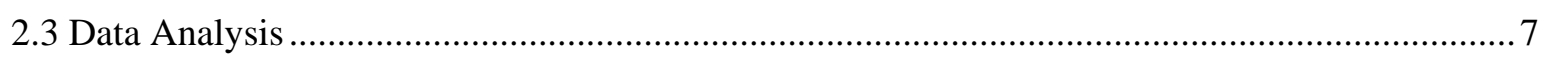

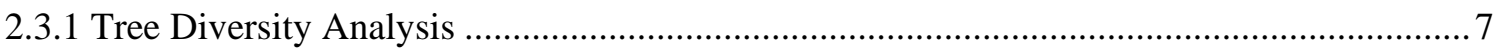

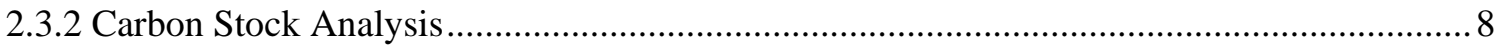

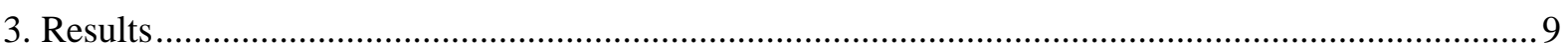

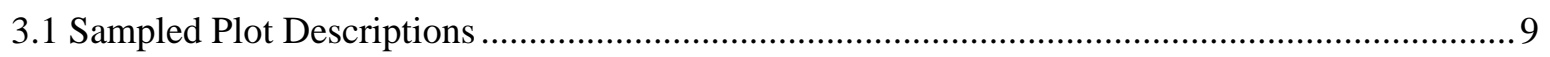

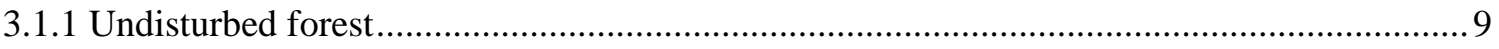

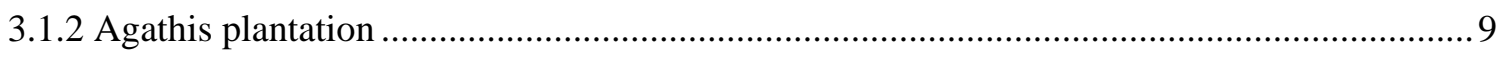

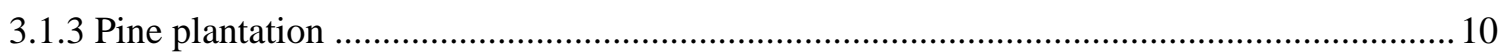

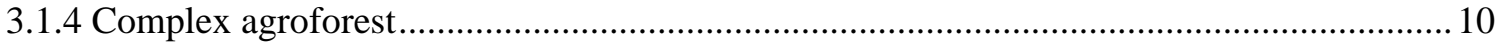

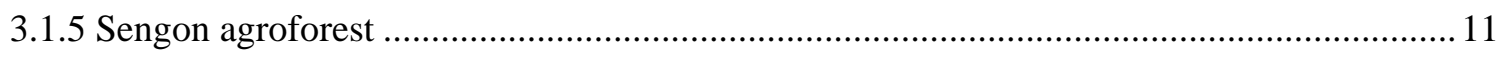

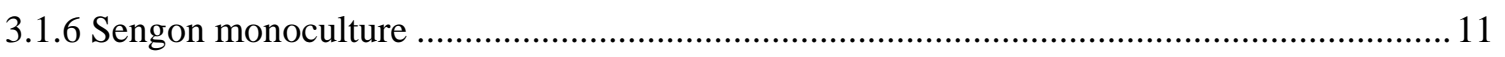

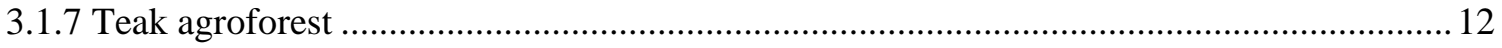

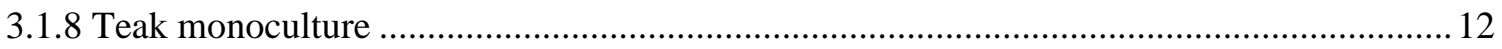

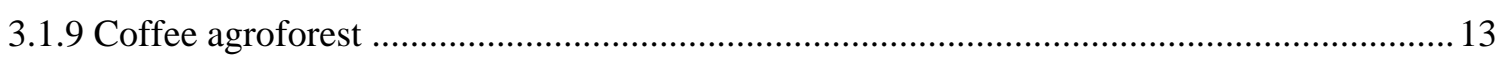

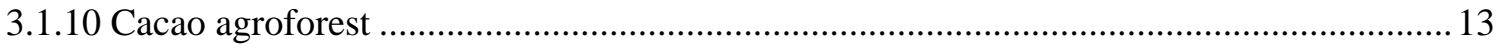

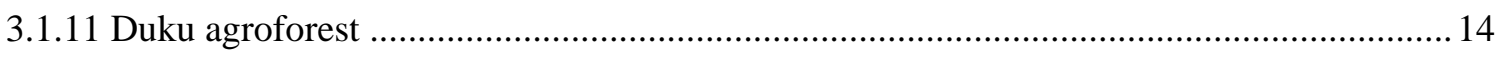

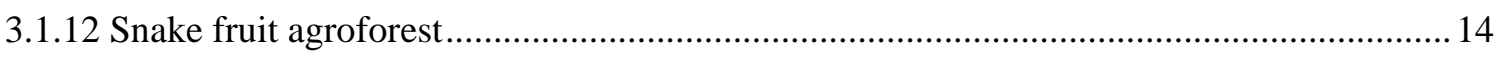

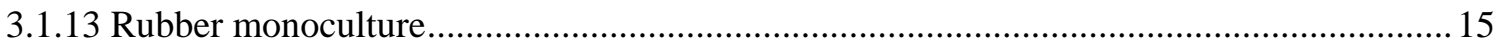

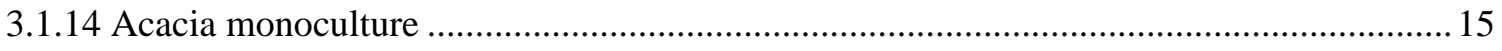

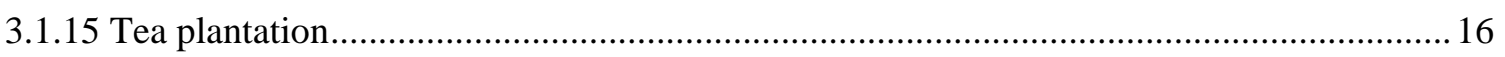

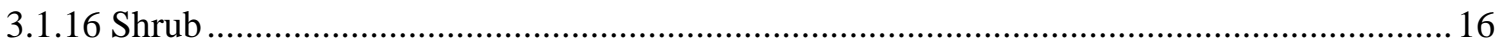

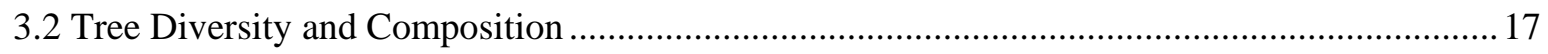

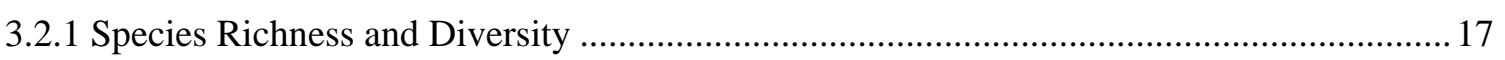

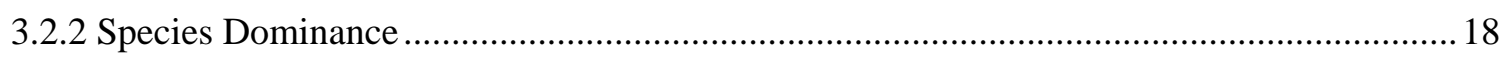

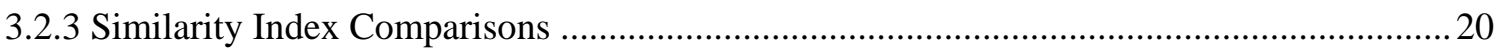

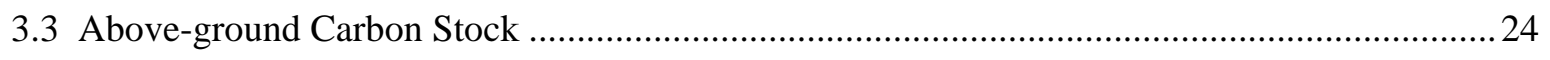

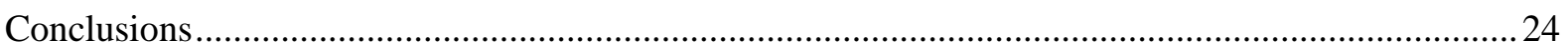

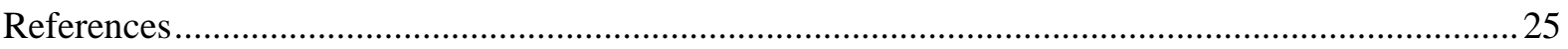




\section{List of Tables}

Table 1. Number of plots in various land use systems in Banyumas, Banjarnegara and

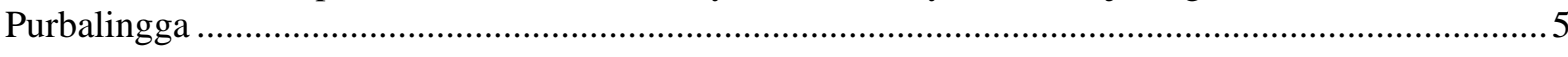

Table 2. Allometric equations for biomass estimation of specific species ….................................... 8

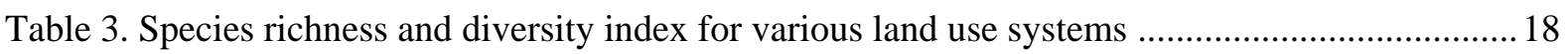

Table 4. Three most dominant species in various land use systems ................................................... 19

Table 5. Similarity matrix of seedling, sapling, pole and tree species among land uses systems.........21

Table 6. Above-ground carbon stock of various land use systems .....................................................24

\section{List of Figures}

Figure 1. Site study

Figure 2. Land use systems in three districts of Banyumas (a), Banjarnegara (b) and Purbalingga (c) .5

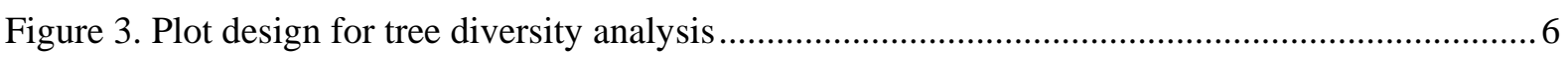

Figure 4. Plot design for carbon stock estimation analysis ............................................................. 7

Figure 5. Undisturbed forest on Slamet Mountain in Purbalingga, Central Java.................................. 9

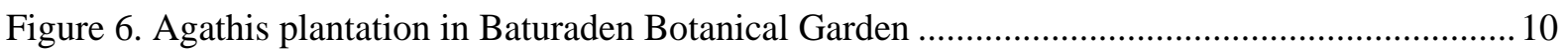

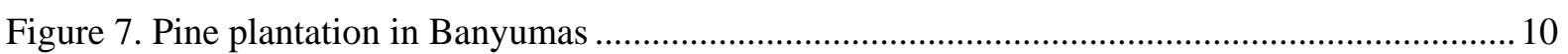

Figure 8. Complex agroforest timber and fruit species based in Banyumas ...................................... 11

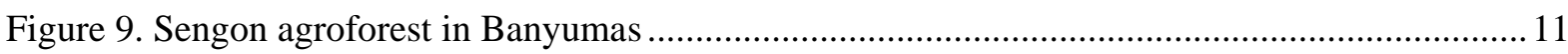

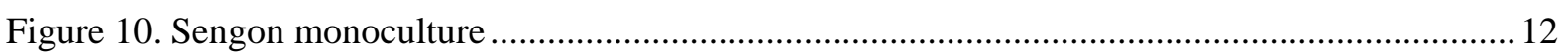

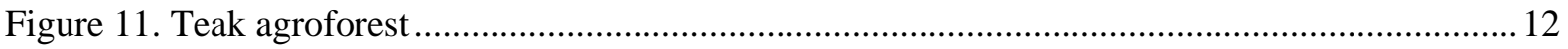

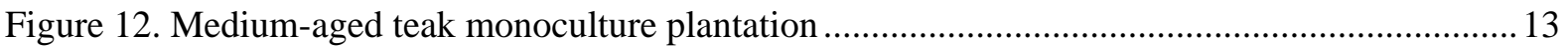

Figure 13. Coffee agroforest in Purbalingga, using sengon as shade trees ......................................... 13

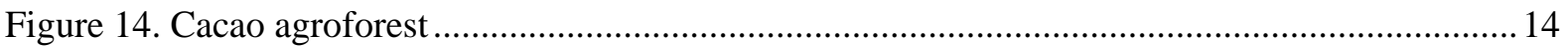

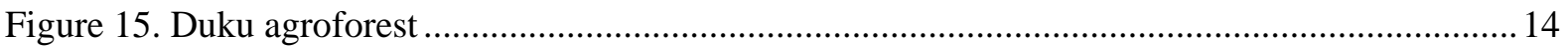

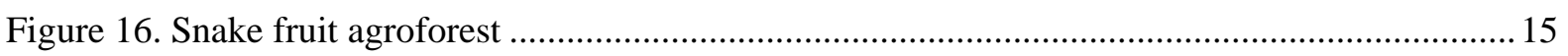

Figure 17. Rubber monoculture plantation aged 11 years ............................................................. 15

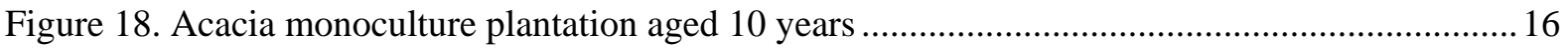

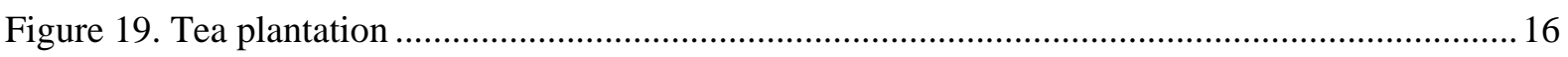

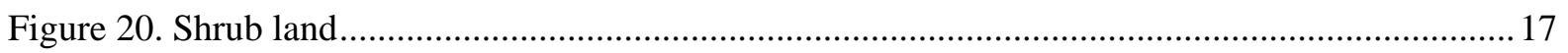




\section{Introduction}

Banyumas, Banjarnegara and Purbalingga are located in the western part of Central Java Province. From the Serayu watershed perspective, Banjarnegara is located upstream, while Purbalingga and Banyumas are midstream. The hilly topography of northern Banjarnegara is currently dominated by horticultural systems, mostly for vegetables such as potato, cabbage and mushroom. Tea and pine plantations are other sources of land-based products in the area. Rice paddies and various compositions of agroforestry systems have spread out in the middle and southern parts of Banjarnegara, Banyumas and Purbalingga.

Monoculture potato plantations are potentially a source of emissions due to land use change from a higher carbon content, as well as losing environmental services due to the loss of tree diversity. Another source emission may be come from rice paddies due to inorganic fertilizer application and other unfriendly environmental practices.

Green Economy and Locally-Appropriate Mitigation Actions in Indonesia (GE-LAMA-I) is an initiative for building local government capacities in low emission development planning and developing locally and/or nationally appropriate mitigation actions. Baseline data for low emission development planning of the current and the past land cover condition, carbon stocks in various land use systems and tree biodiversity as environmental indicators are part of the input for planning development. The aims of the assessment undertaken were: (1) to inventory tree diversity across land use systems and (2) to estimate the carbon stock in various tree-based systems.

\section{Methods}

\subsection{Study Site}

The assessment covered three districts of Banyumas, Banjarnegara and Purbalingga, Central Java (Figure 1). The assessment was conducted in three phases: 9-19 August 2015, 22 May-4 June 2016 and 24-28 August 2016. 


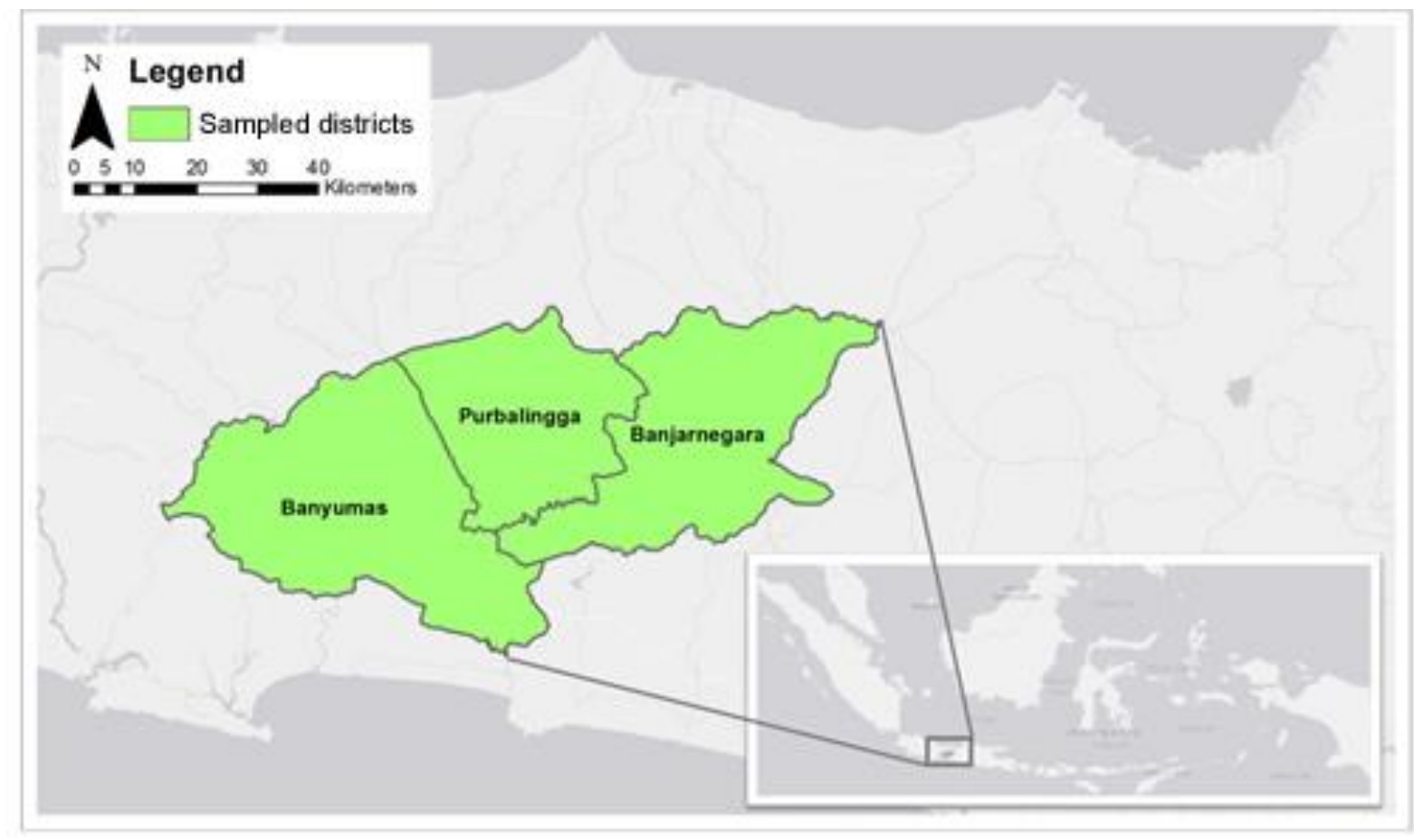

Figure 1. Site study

In total, 75 plots were set up in 16 selected land use systems available in the three districts (Figure 2), with 49 plots in Banyumas, 15 plots in Banjarnegara and 11 plots in Purbalingga (Table 1). 


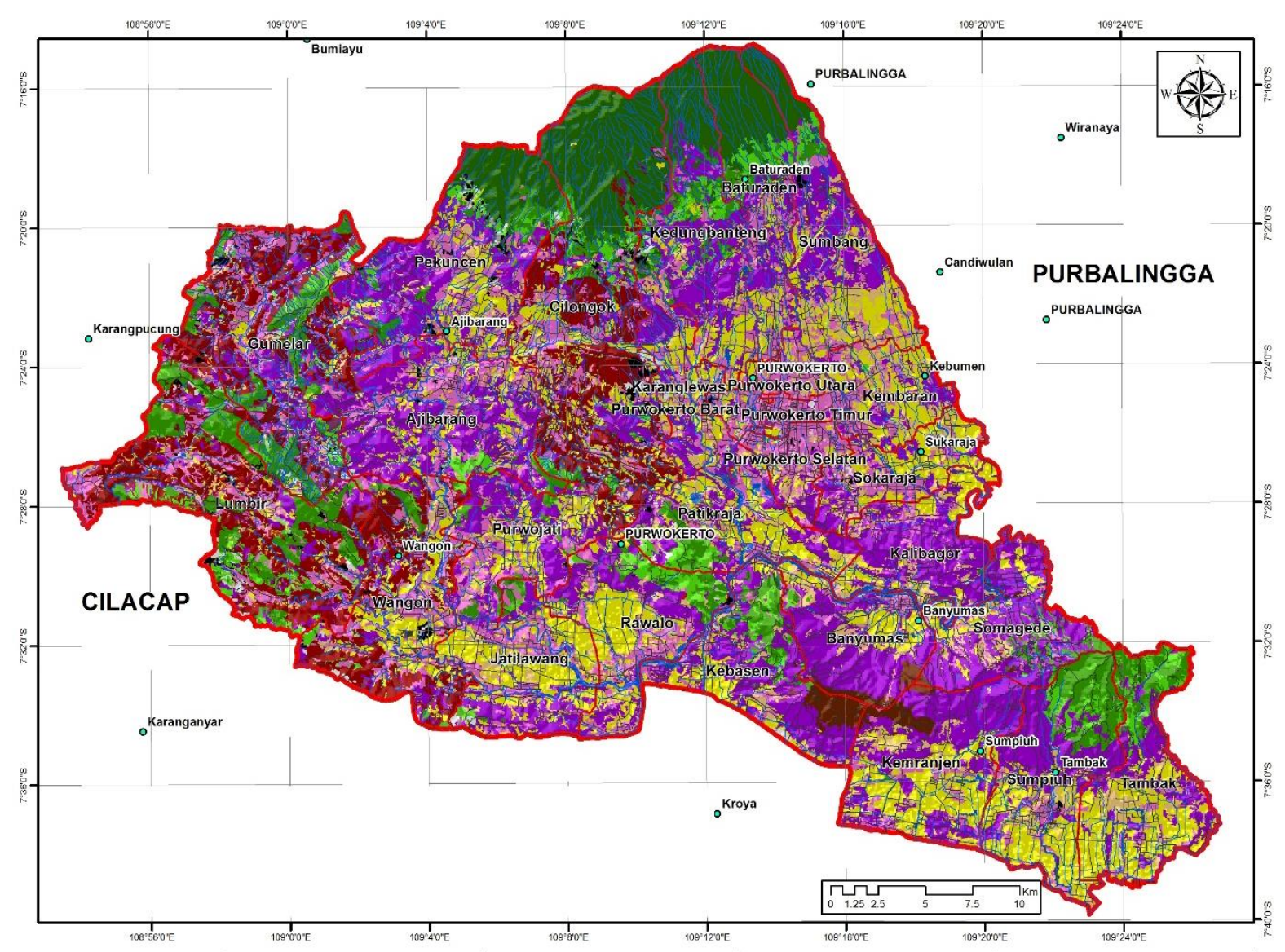

\begin{tabular}{|c|c|c|c|c|c|}
\hline \multicolumn{6}{|c|}{ Legend } \\
\hline o & Toponimi & Banyumas 2014 & Agroforestri jati & Sawah irigasi & Lahan terbuka \\
\hline & Sungai & Hutan primer & Kebun campuran & Tanaman hortikultura dan palawija & Pemukiman \\
\hline$\longrightarrow$ & Jalan & Hutan pinus & Karet monokultur & Semak belukar & Tubuh air \\
\hline & Batas kabupaten & Hutan damar & Coklat monokultur & Padang rumput & Awan \\
\hline & Batas kecamatan & & & & Bayangan \\
\hline
\end{tabular}

a. Banyumas districts 


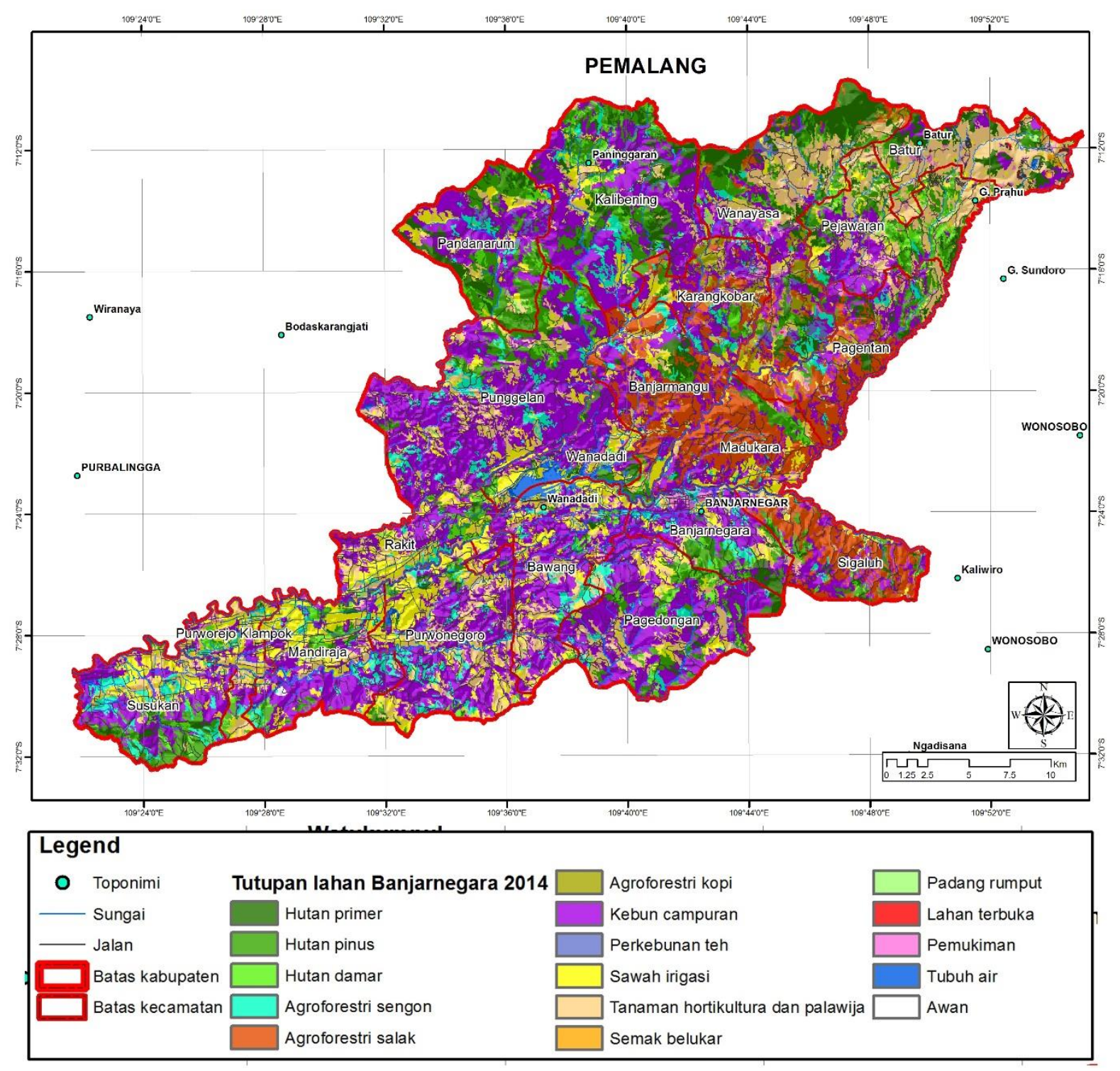

b. Banjarnegara districts 


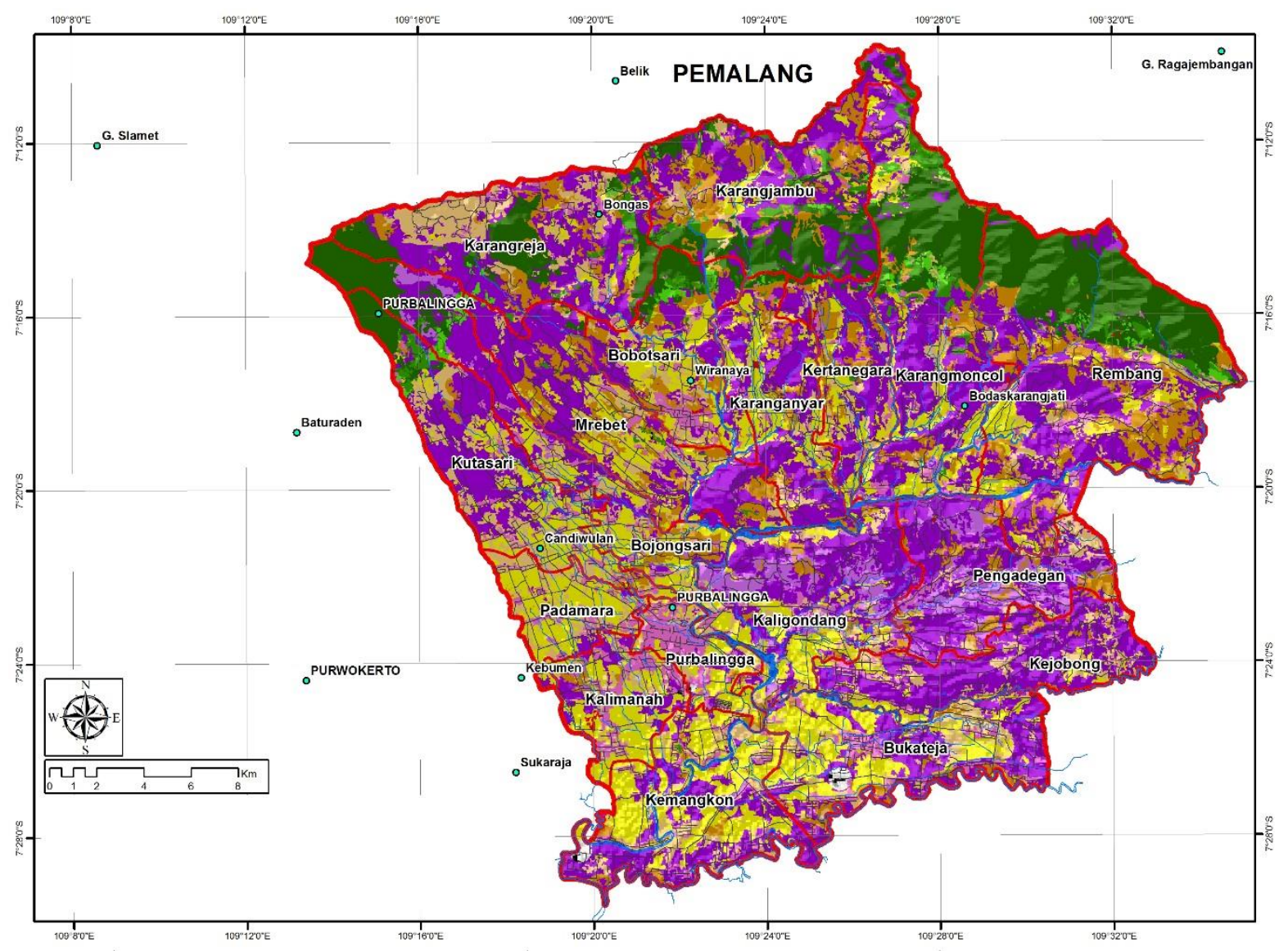

\begin{tabular}{|c|c|c|c|c|}
\hline \multicolumn{5}{|c|}{ Legend } \\
\hline 0 & Toponimi & Purbalingga2014 & Agroforestri duku & Lahan terbuka \\
\hline & River & Hutan primer & Kebun campuran & Pemukiman \\
\hline$\longrightarrow$ & Road & Hutan pinus & Sawah irigasi & Tubuh air \\
\hline & District Boundaries & Hutan damar & Tanaman hortikultura dan palawija & Awan \\
\hline & Subdistrict Boundaries & Agroforesti sengon & Semak belukar & Bayangan \\
\hline
\end{tabular}

c. Purbalingga districts

Figure 2. Land use systems in three districts of Banyumas (a), Banjarnegara (b) and Purbalingga (c)

Table 1. Number of plots in various land use systems in Banyumas, Banjarnegara and Purbalingga

\begin{tabular}{llc}
\hline District & Land use system & Number of plots \\
\hline Banjarnegara & Sengon agroforest & 2 \\
& Sengon monoculture & 2 \\
& Coffee agroforest & 1 \\
& Complex agroforest & 2 \\
& Pines plantation & 3 \\
& Shrub & 1 \\
& Snakefruit agroforest & 2 \\
\hline Banyumas & Tea plantation & 2 \\
\hline & Acacia plantation & 3 \\
& Agathis plantation & 5
\end{tabular}




\begin{tabular}{llr}
\hline District & Land use system & Number of plots \\
\hline & Sengon agroforest & 4 \\
& Sengon monoculture & 3 \\
& Cacao agroforest & 3 \\
& Complex agroforest & 3 \\
& Pines plantation & 3 \\
& Rubber monoculture & 11 \\
& Shrub & 1 \\
& Teak agroforest & 7 \\
& Teak monoculture & 6 \\
\hline Purbalingga & Agathis plantation & 1 \\
& Sengon agroforest & 1 \\
& Sengon monoculture & 1 \\
& Coffee agroforest & 2 \\
& Duku agroforest & 3 \\
& Undisturbed forest & 3 \\
\hline
\end{tabular}

\subsection{Sampling Methods}

The same plot was used for tree diversity sampling and the carbon stock inventory. A modified plot size was used ( $5 \times 20 \times 20 \mathrm{~m}$ ) with nested smaller plots (Figure 3) used to sample tree diversity. Carbon stock estimation use the method described in Hairiah et al. (2011). A $2000 \mathrm{~m}^{2}$ plot (20 x 100 m) was placed in the targeted land cover (Figure 4).

\subsubsection{Tree diversity}

Four stages of vegetation growth were considered: seedlings ( $<2 \mathrm{~m}$ height), saplings ( $\geq 2 \mathrm{~m}$ height, $<5$ $\mathrm{cm}$ stem diameter), poles (5-10 $\mathrm{cm}$ diameter) and trees ( $>10 \mathrm{~cm}$ diameter), with nested sampling of plots ( $2 \mathrm{~m} \times 2 \mathrm{~m}$ for seedlings, $5 \mathrm{~m}$ x $5 \mathrm{~m}$ for saplings, $10 \mathrm{~m} \times 10 \mathrm{~m}$ for poles and $20 \times 20 \mathrm{~m}$ for trees).

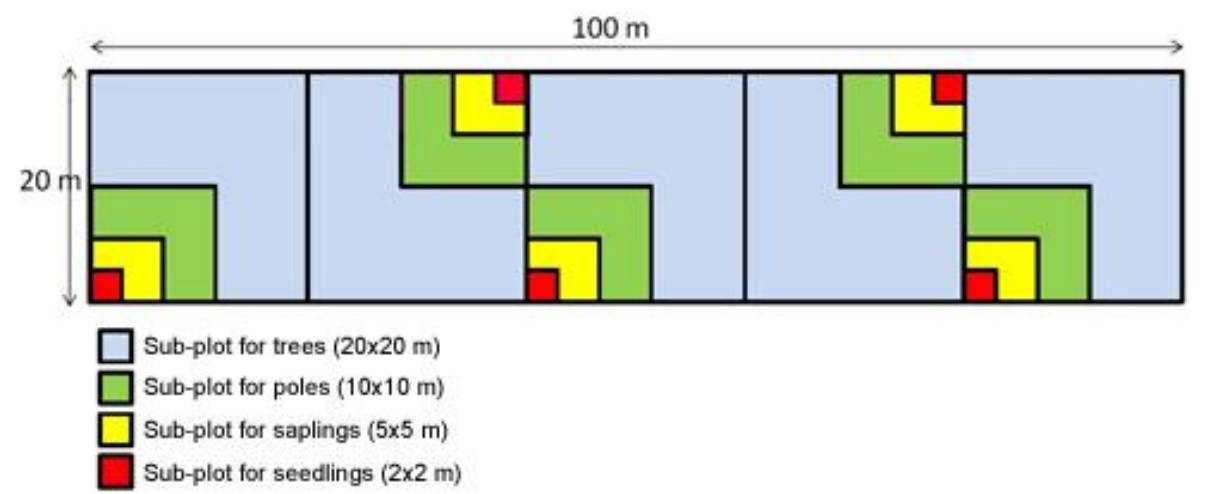

Figure 3. Plot design for tree diversity analysis

All seedlings and saplings included in the plot samples were enumerated and each species was identified. All stem diameters of poles and trees in the plot samples were measured at breast height (1.3 meters above-ground surface; DBH) and identified. Leaf specimens of all species were collected and identified in the Herbarium Bogoriense, at Cibinong, Indonesia. 


\subsubsection{Above-ground Carbon Stock}

Four carbon pools were included in the assessment: tree biomass, understorey, tree necromass and litter. Biomass estimation for large living and dead trees above $30 \mathrm{~cm} \mathrm{DBH}$ were determined in the 20 x $100 \mathrm{~m}$ plot, while the smaller living and dead trees 5-30 cm DBH were measured in the $40 \mathrm{x} 5 \mathrm{~m}$ plot (Figure 4). The decomposition factor for dead trees was estimated based on visual inspection.

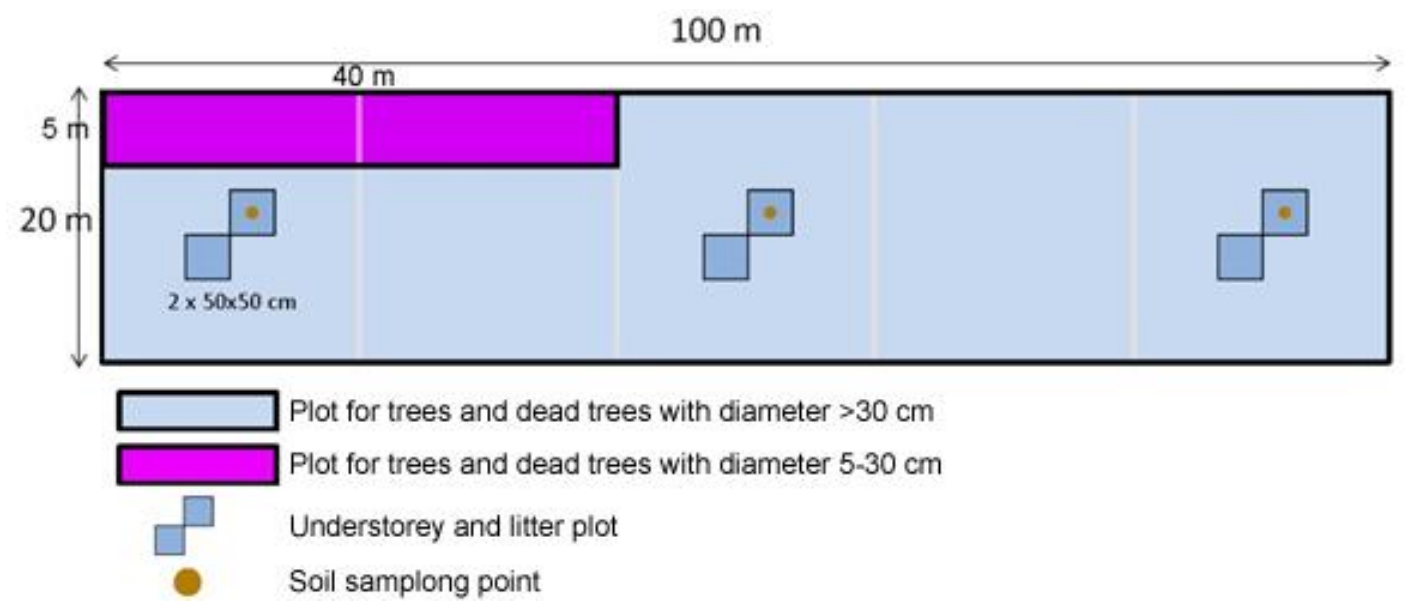

Figure 4. Plot design for carbon stock estimation analysis

Understorey and litter sampling were conducted in a set of quadrants $(2 \times 0.5 \times 0.5 \mathrm{~m})$ placed randomly inside the $20 \times 100 \mathrm{~m}$ plot, with a minimum of three replications in each plot. The fresh and dry weights of the understorey and litter samples were used in this analysis.

A specific semi destructive sampling method was developed to estimate snakefruit (salak) biomass. Three salak leaves selected using three length criteria (short, medium and long relative to all leaves in the plot) were taken from each salak clump in the $20 \times 100 \mathrm{~m}$ plot. The weights of fresh and dry leaves, stalks and fronds were used to estimate the dry matter percentage of leaves. The total leaf weight in the plot was determined using multiplication factors.

\subsection{Data Analysis}

\subsubsection{Tree Diversity Analysis}

Species richness, important value index (IVI), similarity index using the Bray-Curtis dissimilarity index and the Shannon-Wiener diversity index were used for the tree diversity analysis. Species richness is the number of different species represented in an ecological community, landscape or region (Colwell, 2009). IVI expresses the dominance of species per unit area based on the relative frequency, relative density and relative dominance (Curtis \& McIntosh 1950):

$$
I V I=\text { Relative Frequency }+ \text { Relative Density }+ \text { Relative Dominance }
$$

a. Relative frequency: Frequency of species $i=\frac{\text { Number of quadrats species } i}{\text { Total number of quadrat sampled }}$

$$
\text { Relative Frequency }=\frac{\text { Frequency of species } i}{\text { Total Frequency }}
$$

b. Relative density: Density of species $i=\frac{\text { Number of species } i}{\text { Area of quadrat sampled }}$

$$
\text { Relative Density }=\frac{\text { Density of species } i}{\text { Total density }}
$$


c. Relative dominance: Dominance (Basal area of species $i)=\frac{\pi *(\text { Diameter of species } i)^{2}}{4}$

$$
\text { Relative Dominance }=\frac{\text { Basal area of species } i}{\text { Total basal area }}
$$

Bray-Curtis dissimilarity (B) is a statistic used to quantify the compositional dissimilarity between two different sites, based on counts at each site. Bray-Curtis dissimilarity uses individual numbers as a parameter in the calculation, so that it involves both species and individual parameters affecting the degree of similarity between two compared sites.

$$
\text { Bray-Curtis similarity }(1-B)=1-\frac{\sum_{i=1}^{S}\left|\left(n_{1 i}-n_{2 i}\right)\right|}{\sum_{i=1}^{S}\left(n_{1 i}+n_{2 i}\right)}
$$

where:

$B=$ Bray-Curtis dissimilarity

$S=$ total species number in land use 1 and land use 2

$n_{1}=$ number of individual species $i$ in land use 1

$n_{2}=$ number of individual species $i$ in land use 2

The Shannon-Wiener diversity index $\left(\mathrm{H}^{\prime}\right)$ is a popular index used in ecological studies. It represents the species heterogeneity of a site and incorporates species richness and evenness. The value of the Shannon-Wiener index commonly varies between 0 and 3.5 and rarely surpasses 4.5 .

$$
H^{\prime}=-\sum p i(\ln p i)
$$

where, $p i=$ proportion of individual number of each species to total species $i$

The value of H' represents species heterogeneity and is classified into: low (H'<1.5), medium (1.53.5) and high $\left(H^{\prime}>3.5\right)$.

\subsubsection{Carbon Stock Analysis}

The above-ground tree biomass of general species was calculated using the allometric equation developed by Chave et al. (2005) for humid/moist topical forest stands with precipitation between $1500 \mathrm{~mm}$ and $4000 \mathrm{~mm} / \mathrm{year}$ :

$$
\begin{aligned}
& \text { Above - Ground Biomass.est }(\mathrm{kg}) \\
& \qquad=\rho * \operatorname{esp}\left(-1.499+2.148 \ln (D)+0.207(\ln (D))^{2}-0.0281(\ln (D))^{3}\right)
\end{aligned}
$$

However, for specific species, we used allometric equations developed by various researchers compiled in Hairiah et al. (2011) (Table 2).

Table 2. Allometric equations for biomass estimation of specific species

\begin{tabular}{lll}
\hline Species & Allometric Equation & Source \\
\hline Coffee regularly pruned & (AGB)est $=0.281 \mathrm{D}^{2.06}$ & Arifin, 2001 \\
Cacao & (AGB)est $=0.1208 \mathrm{D}^{1.98}$ & Yuliasmara, 2008 \\
Oil palm & (AGB)est $=0.0976 \mathrm{H}+0.0706$ & ICRAF, 2009 \\
Palm & (AGB)est $=\exp \{-2.134+2.530 \times \ln (\mathrm{D})\}$ & Brown, 1997 \\
Palm & (AGB)est $=4.5+7.7 \times \mathrm{H}$ & Frangi and Lugo, 1985 \\
Bamboo & $\left(\right.$ AGB)est $=0.131 \mathrm{D}^{2.28}$ & Priyadarsini, 2000 \\
Banana & (AGB)est $=0.030 \mathrm{D}^{2.13}$ & Arifin, 2001 \\
\hline
\end{tabular}

Note: (AGB)est = estimation above-ground tree biomass, $\mathrm{kg} / \mathrm{tree} ; \mathrm{D}=\mathrm{DBH}$, diameter at breast height, $\mathrm{cm} ; \mathrm{H}=$ tree height, $\mathrm{m} ; \rho=$ Wood density, $\mathrm{gcm}^{-3}$ (available from: http://db.worldagroforestry.org/wd). 


\section{Results}

\subsection{Sampled Plot Descriptions}

\subsubsection{Undisturbed forest}

Undisturbed forest is a typical natural land use composed of native species with a dense canopy and highly diverse species and basal areas (Figure 5). Three plots of undisturbed forest were sampled around Slamet Mountain at -7.22897 and $109.24315^{\circ},-7.22953^{\circ}$ and $109.24301^{\circ},-7.22779^{\circ}$ and $109.24554^{\circ}$. The sampled plots conditions consisted of mountain forest zone in steeply sloping terrain at 1993-2152 meters above sea level (asl).

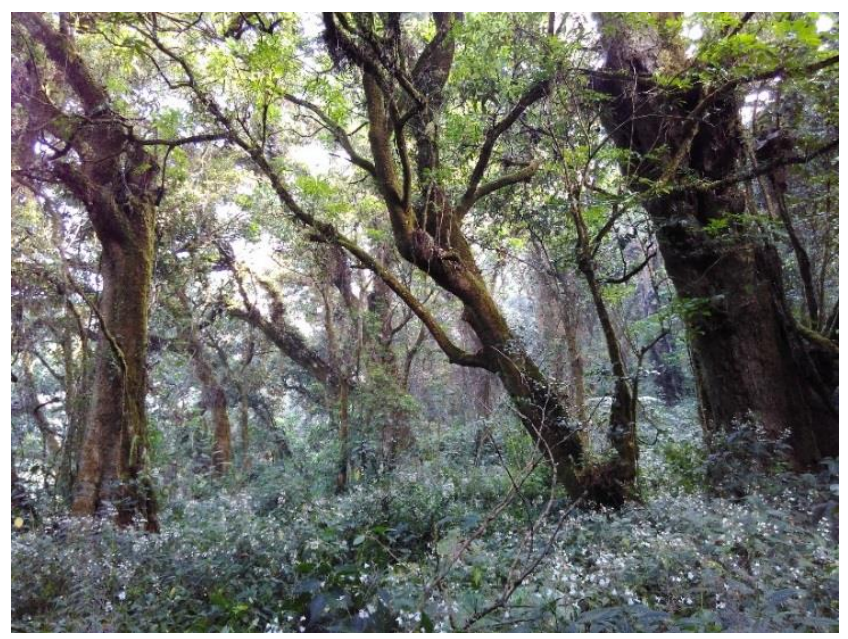

Figure 5. Undisturbed forest on Slamet Mountain in Purbalingga, Central Java

\subsubsection{Agathis plantation}

Agathis (Agathis loranthifolia) plantation was established by PT. Perhutani, as a state plantation operated in Java Island in the Forest Management Unit (FMU) Banyumas Timur (Figure 6). The status of the forest is limited production forest covering 17,552.8 ha including Baturaden Botanical Garden. Besides Agathis loranthifolia, some blocks of puspa (Schima wallichii), pine (Pinus merkusii), rasamala (Altingia excelsa), mahoni (Switenia macrophylla), kaliandra (Callyandra calothyrsus) have been established in the area (Budiana \& Sukarsa, 2012). Six plots of agathis forest were established in Banyumas and Purbalingga at $-7.30786^{\circ}$ and $109.22122^{\circ},-7.30701^{\circ}$ and $109.22675^{\circ},-7.22573^{\circ}$ and $109.31161^{\circ},-7.1823^{\circ}$ and 109.1405 . However, two plots of agathist forest co-ordinate were not recorded. Plots were set up in various ages of plantation from old (60 years), through medium (30 years) to the youngest (10 years). Planting spacing was $5 \times 5 \mathrm{~m}$ in the agathis planting at 772-993 meters asl. 


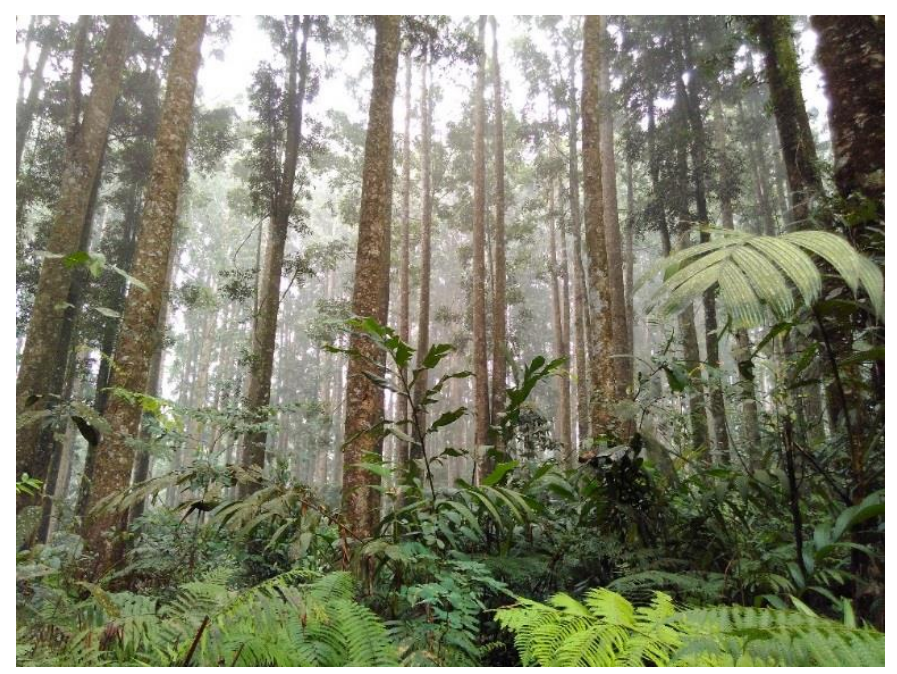

Figure 6. Agathis plantation in Baturaden Botanical Garden

\subsubsection{Pine plantation}

Monoculture plantation of pine (Pinus merkusii) was established by PT. Perhutani in FMU Banyumas Timur (Figure 7). Six plots of pines plantation were established in Banyumas and Banjarnegara at 7.429119 and $108.96798^{\circ},-7.42936^{\circ}$ and $108.95044^{\circ},-7.51592^{\circ}$ and $109.20394^{\circ},-7.1728^{\circ}$ and $109.3641^{\circ},-7.1434^{\circ}$ and $109.3802^{\circ},-7.1427^{\circ}$ and $109.3851^{\circ}$. The status of the forest is limited production forest covering 28,897.46 ha. The planting spacing was 8-10 meters. Sampled plots were established various ages of planting from the oldest (40 years) through medium (20 years) to the youngest (10 years) at locations 51-1049 meters asl.

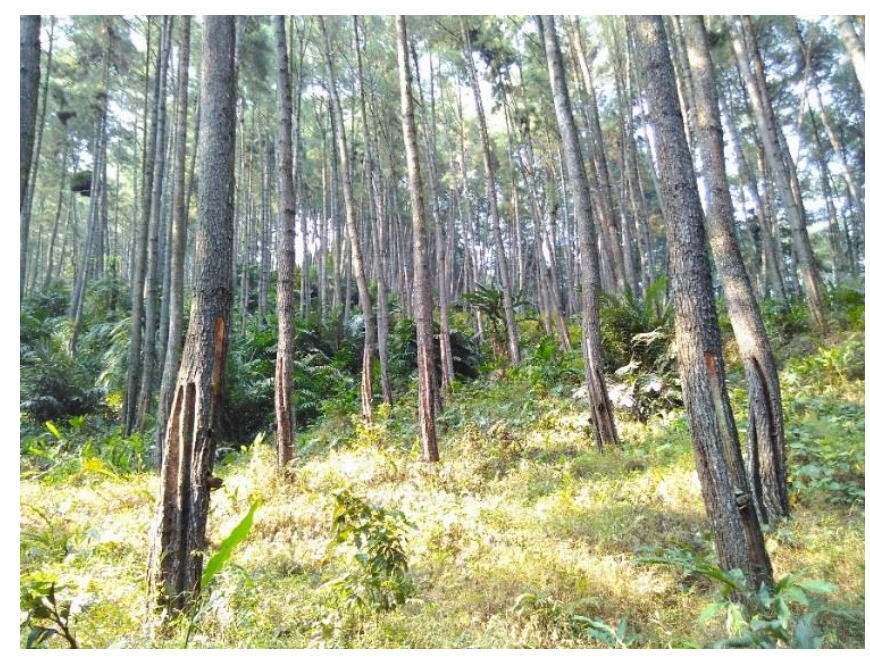

Figure 7. Pine plantation in Banyumas

\subsubsection{Complex agroforest}

Complex agroforest consists of various utilized commodities on a piece of land and is a very common land use system in the area (Figure 8). The timber product of sengon (Paraserianthes falcataria) is a popular commodity in the districts in combination with some fruit trees, bamboo and other species. There is a complex age structure and sizing, with species occurring in a random pattern. Five plots of complex agroforest were established in Banyumas and Banjarnegara at $-7.44095^{\circ}$ and $109.14123^{\circ}$, $7.47594^{\circ}$ and $109.20743^{\circ},-7.45207^{\circ}$ and $109.51150^{\circ},-7.416663^{\circ}$ and $109.045575^{\circ},-7.480814^{\circ}$ and $109.385196^{\circ}$ between $60-134$ meters asl. 


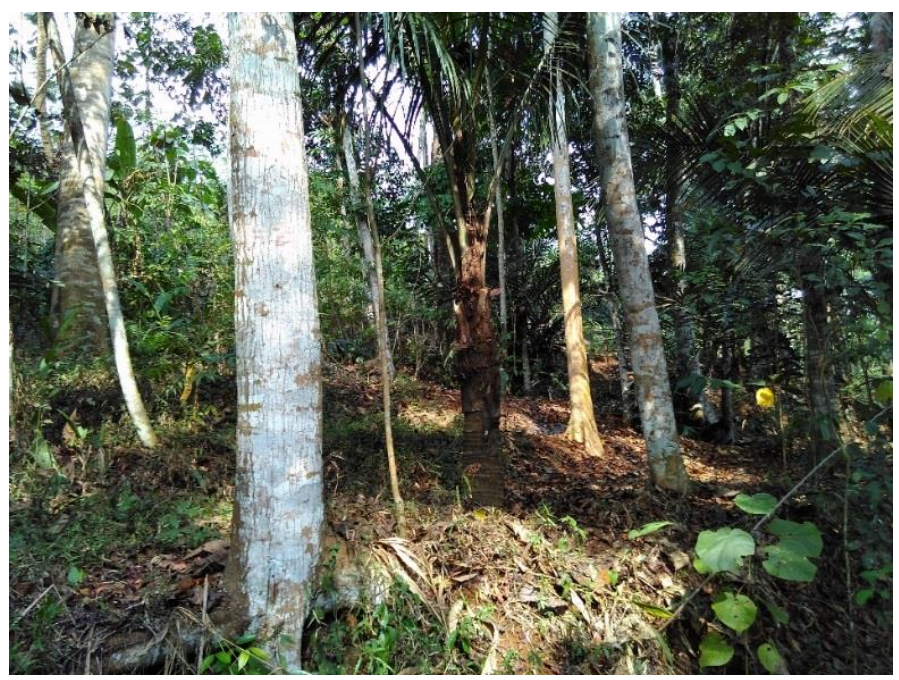

Figure 8. Complex agroforest timber and fruit species based in Banyumas

\subsubsection{Sengon agroforest}

Sengon agroforest is a land use type dominated by sengon (Paraserianthes falcataria) combined with other tree species (Figure 9). The timber of sengon is very popular in the area and commands a good price. Various plants integrated in the sengon plantation include cassava, coffee and sometimes fruits or another timber species. Seven plots of sengon agroforest were established in Banyumas,

Purbalingga and Banjarnegara at $-7.53672^{\circ}$ and $109.34338^{\circ},-7.36187^{\circ}$ and $109.27467^{\circ},-7.422331^{\circ}$ and $108.961959^{\circ},-7.526845^{\circ}$ and $109.315533^{\circ},-7.394268^{\circ}$ and $109.614771^{\circ},-7.351522^{\circ}$ and $109.588221^{\circ},-7.356141^{\circ}$ and 109.523319 at $25-297$ meters asl.

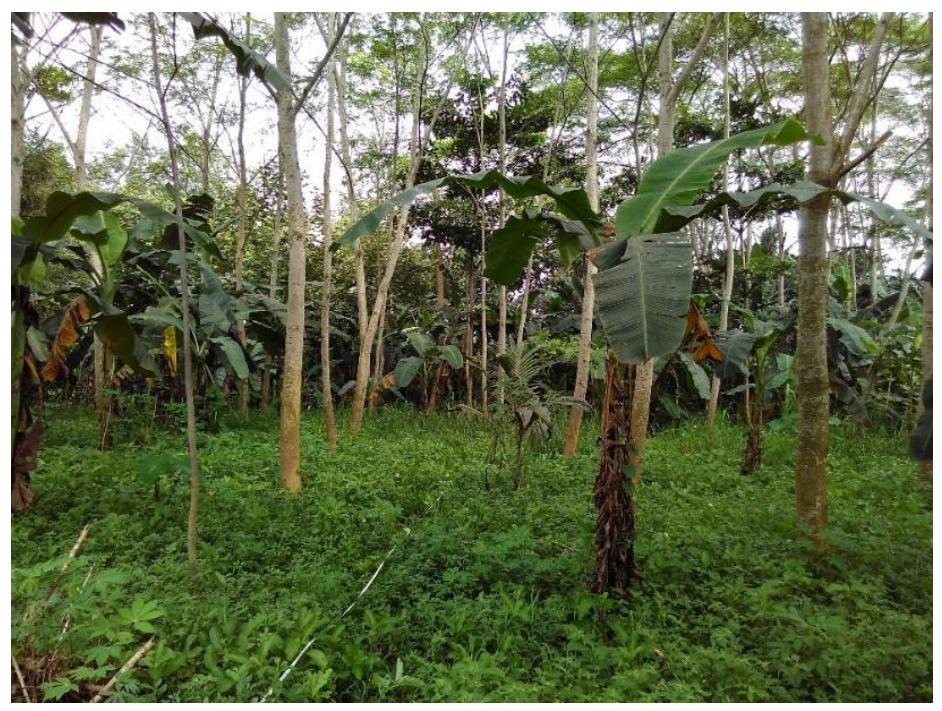

Figure 9. Sengon agroforest in Banyumas

\subsubsection{Sengon monoculture}

Sengon monoculture is intensively managed. Weeding is undertaken periodically in the younger stands ( $2 \mathrm{~m} \times 2 \mathrm{~m}$ spacing) and in the older stands (4x4 meters spacing) (Figure 10). Thinning occurs while the plants are actively growing to provide a better growing environment. Six plots of sengon monoculture were established in Banyumas, Purbalingga and Banjarnegara in young plantations (2-3 years) and medium-aged stands (5-6 years) at $-7.38998^{\circ}$ and $109.27628^{\circ},-7.42057^{\circ}$ and $109.78452^{\circ}$, - 

and $109.375064^{\circ}$ at $50-490$ meters asl.

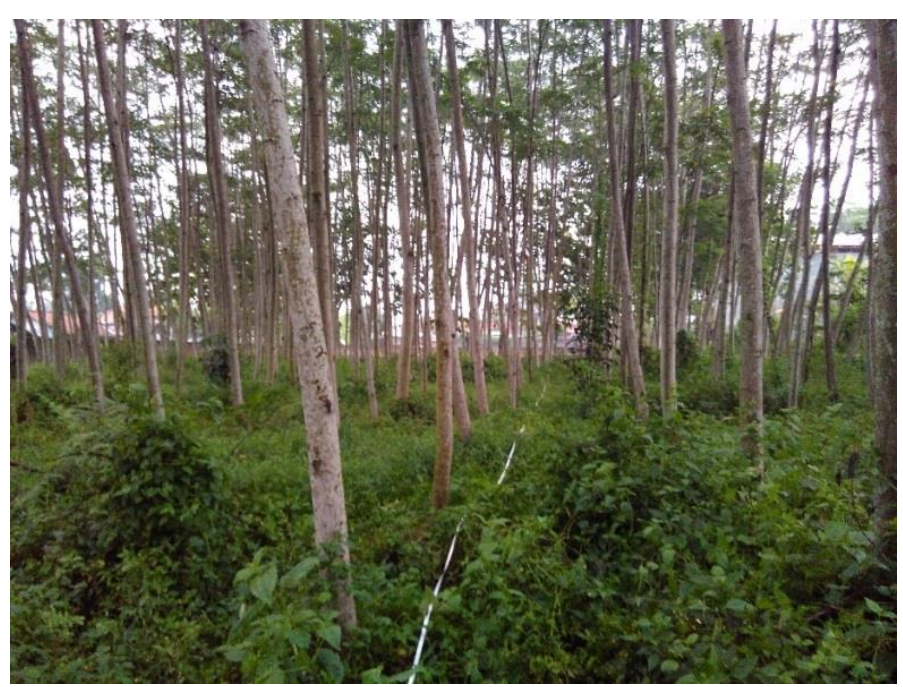

Figure 10. Sengon monoculture

\subsubsection{Teak agroforest}

Teak agroforest is land use type dominated by teak combined with other species such as fruit trees, coconut, coffee, melinjo (Gnetum gnemon) and some other timber species such as sengon, mahogany and acacia. Low intensive management is applied by smallholder farmers (Figure 11). Seven plots of teak agroforest were established in Banyumas at $-7.49941^{\circ}$ and $109.21614^{\circ},-7.48853^{\circ}$ and $109.20917^{\circ},-7.52279^{\circ}$ and $109.33704^{\circ},-7.49157^{\circ}$ and $109.23717^{\circ},-7.518518^{\circ}$ and $109.345560^{\circ}$, $7.517039^{\circ}$ and $109.336745^{\circ},-7.515001^{\circ}$ and 109.266278 at $34-68$ meters asl.

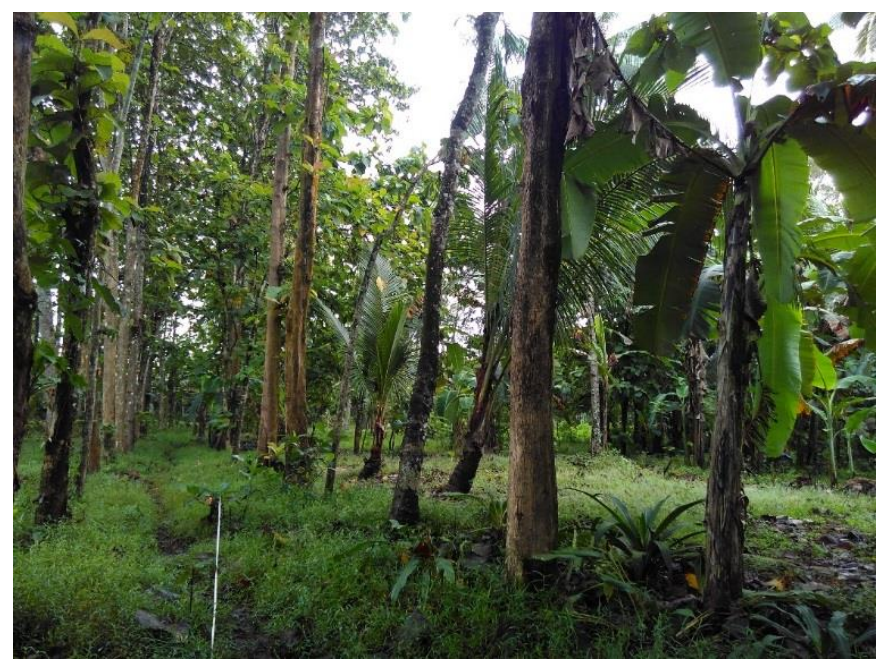

Figure 11. Teak agroforest

\subsubsection{Teak monoculture}

Teak monoculture is a land use type managed intensively with teak (Tectona grandis) as the main commodity (Figure 12). Teak plantations, in both monoculture and agroforest systems are spread out in Banyumas. Some monoculture plantations were established by PT. Perhutani in FMU Banyumas Timur. Six plots of teak monoculture were established in medium-aged teak plantation (10-18 years) with one older plot (above 20 years). Commonly, teak was planted at spacings of $2.5 \times 2.5$ meters up to $5 \times 5$ meters. The plots were located at $-7.430796^{\circ}$ and $109.064089^{\circ},-7.540850^{\circ}$ and $109.064371^{\circ}$, 

and $109.271073^{\circ}$ at $40-194$ meters asl.

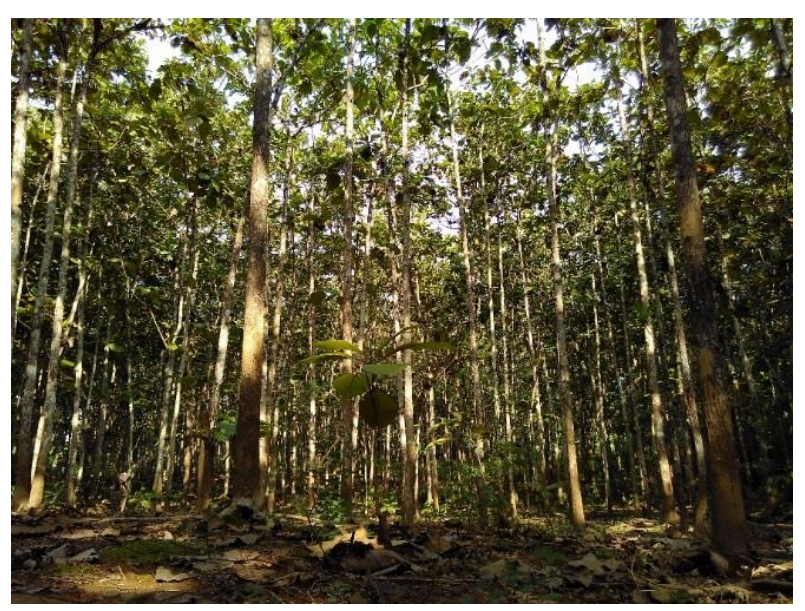

Figure 12. Medium-aged teak monoculture plantation

\subsubsection{Coffee agroforest}

Coffee agroforest integrated with sengon as shading tree was found in Purbalingga (Figure 13) and Banjarnegara. Robusta coffee was cultivated in the lowlands of Purbalingga at around $200 \mathrm{~m}$ asl at a spacing of $1.5 \times 1.5$ meters. However, arabica coffee was found at higher elevation (1100 m asl) in Banjarnegara. Three plots of coffee agroforest were established at $-7.28873^{\circ}$ and $109.82946^{\circ}$, $7.36067^{\circ}$ and $109.50253^{\circ},-7.34534^{\circ}$ and $109.50581^{\circ}$.

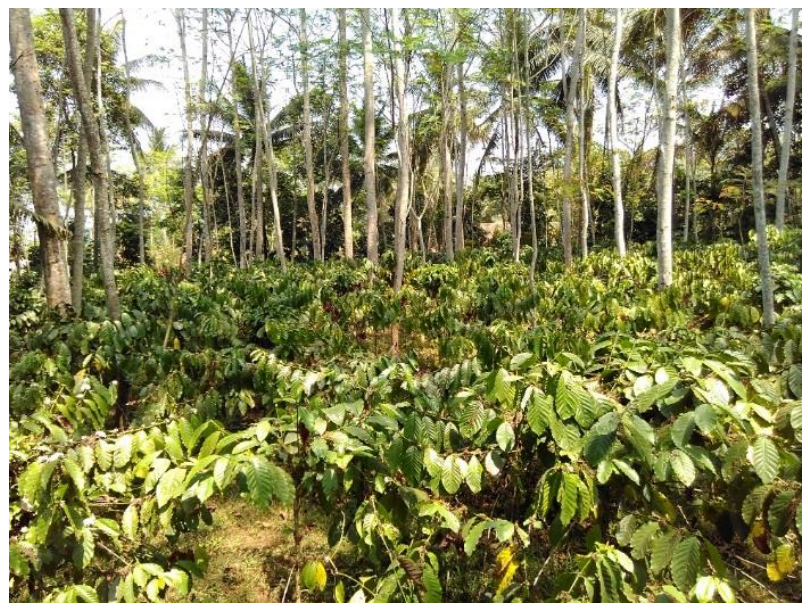

Figure 13. Coffee agroforest in Purbalingga, using sengon as shade trees

\subsubsection{Cacao agroforest}

Cacao agroforest was only found in Banyumas where it had been established by PT. Rumpun Sari Antan IV. Coconut, teak and cassava were integrated in the cacao agroforest system (Figure 14). Three plots of 24-year-old cacao agroforest were established in Darmakradenan, Ajibarang at $7.420196^{\circ}$ and $109.024948^{\circ},-7.421193^{\circ}$ and $109.025020^{\circ},-7.420525^{\circ}$ and $109.025901^{\circ}$ at 150 meters asl. 


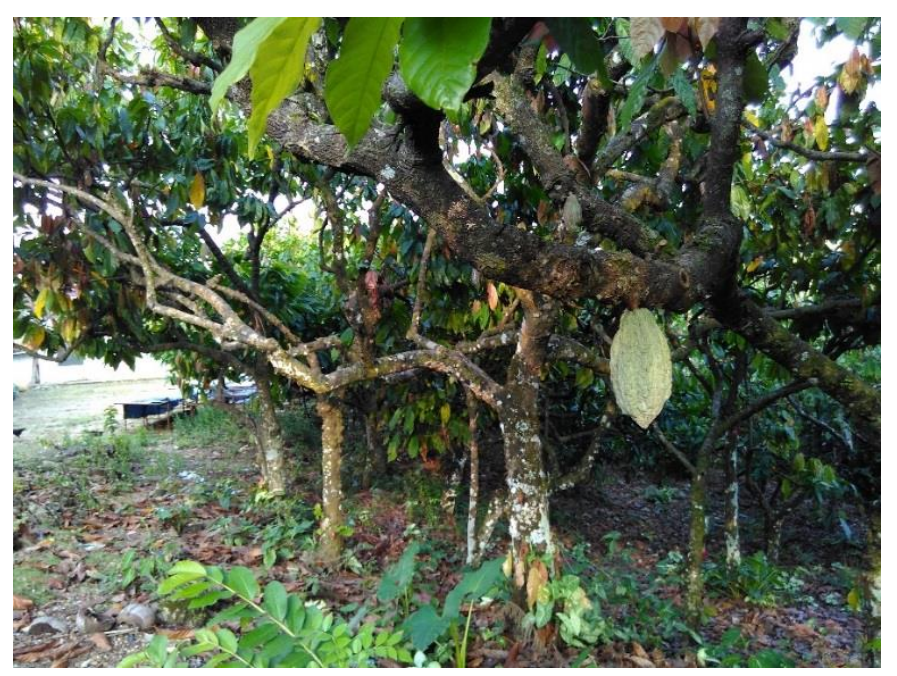

Figure 14. Cacao agroforest

\subsubsection{Duku agroforest}

Duku agroforest is a complex system dominated by duku (Lansium domesticum) (Figure 15) in Kalikajar, Kaligondang, Purbalingga. This system was established as protected area for the duku germplasm as it was considered to represent good fruit quality (RPJMD Purbalingga 2010-2015).

Coconut, sengon and rambutan are integrated in the duku system. Three plots of duku agroforest were established at $-7.36633^{\circ}$ and $109.38403^{\circ},-7.37973^{\circ}$ and $109.38595^{\circ},-7.36504^{\circ}$ and $109.38203^{\circ}$ at $73-$ 198 meters asl.

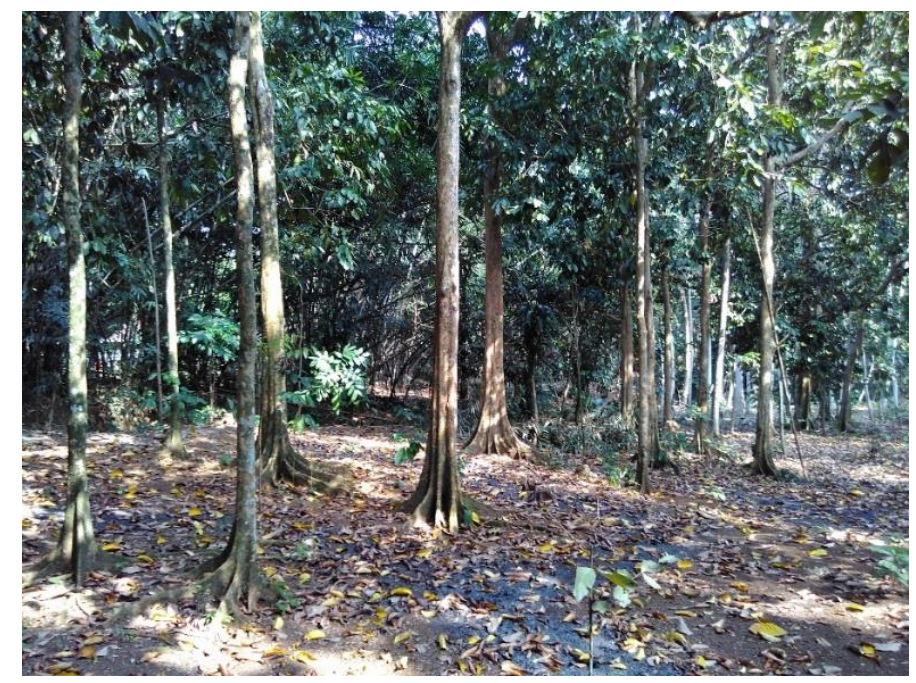

Figure 15. Duku agroforest

\subsubsection{Snake fruit agroforest}

Snake fruit (salak) is cultivated in intensively managed areas using organic farming under various species such as damar, mahogany, aren, jackfruit, coconut, sengon, avocado and petai (Figure 16) and was commonly found in Banjarnegara. Snake fruit plants are planted at spacings of $2.5 \times 2.5$ meters or $1.5 \times 1.5$ meters under the tree canopy. Two plots of snake fruit agroforest were established at $7.34694^{\circ}$ and $109.68428^{\circ},-7.401241^{\circ}$ and $109.775271^{\circ}$ at $365-423$ meters asl. 


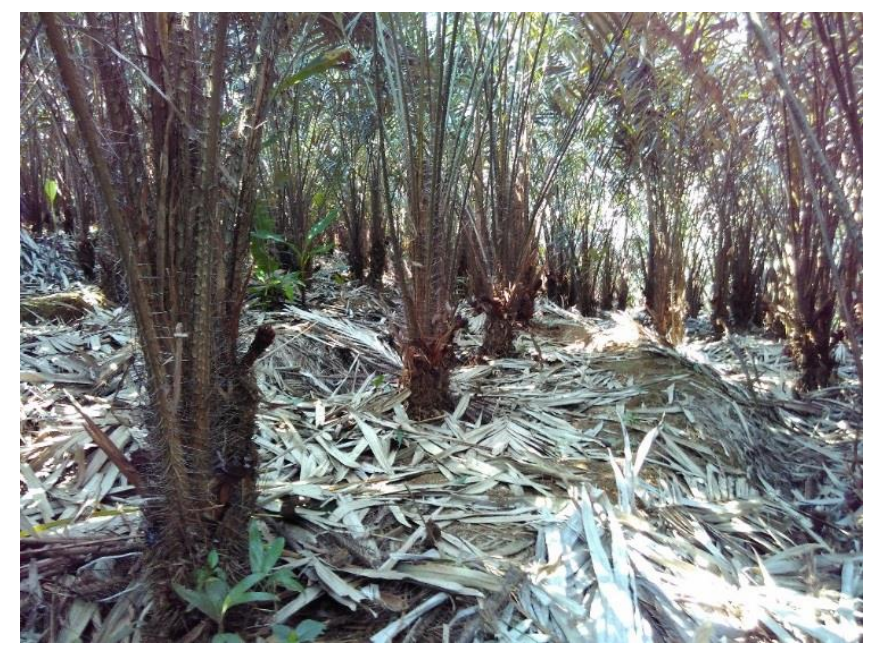

Figure 16. Snake fruit agroforest

\subsubsection{Rubber monoculture}

The rubber monoculture in Banyumas (2,051.25 ha) was established by PT. Perkebunan Nusantara IX Unit Kerja Kebun Krumput (Figure 17). The plantation is located in two administrative districts, Banyumas (1,202.88 ha) in Krumput and Tumiyang division and in Cilacap (848.37 ha) which includes Kubangkangkung division. In Banyumas, rubber plantation hasbeen established in hilly areas at 50-400 meters asl in Latosol and Regosol soil types. Rubber trees planted from 1996 to 2011 are spaced at 3 × 6 meters. Eleven plots of rubber monoculture aged 1-19 years were established in Banyumas: $-7.57378^{\circ}$ and $109.27650^{\circ},-7.57319^{\circ}$ and $109.26584^{\circ},-7.55660^{\circ}$ and $109.26309^{\circ}$, $7.57046^{\circ}$ and $109.28422^{\circ},-7.571732^{\circ}$ and $109.265285^{\circ},-7.569380^{\circ}$ and $109.262794^{\circ},-7.563276^{\circ}$ and $109.271867^{\circ},-7.563411^{\circ}$ and $109.283512^{\circ},-7.563307^{\circ}$ and $109.279549^{\circ},-7.564955^{\circ}$ and $109.278140^{\circ},-7.564683^{\circ}$ and $109.279861^{\circ}$.

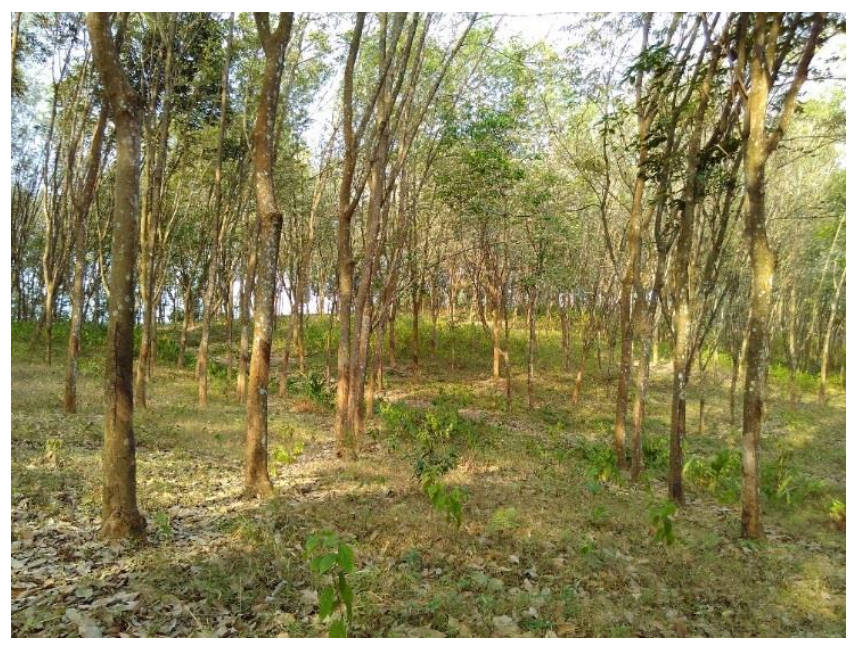

Figure 17. Rubber monoculture plantation aged 11 years

\subsubsection{Acacia monoculture}

Acacia monoculture plantation (Figure 18) was found in Banyumas having been established by PT. Perhutani in Banyumas Timur. Plant spacings of $2 \times 3$ meters and $5 \times 5$ meters were applied by the company. Three plots of 10-year-old acacia monoculture were established at 100 meters asl, however only one co-ordinate location that recorded $\left(-7.3016^{\circ}\right.$ and $\left.109.0624^{\circ}\right)$. 


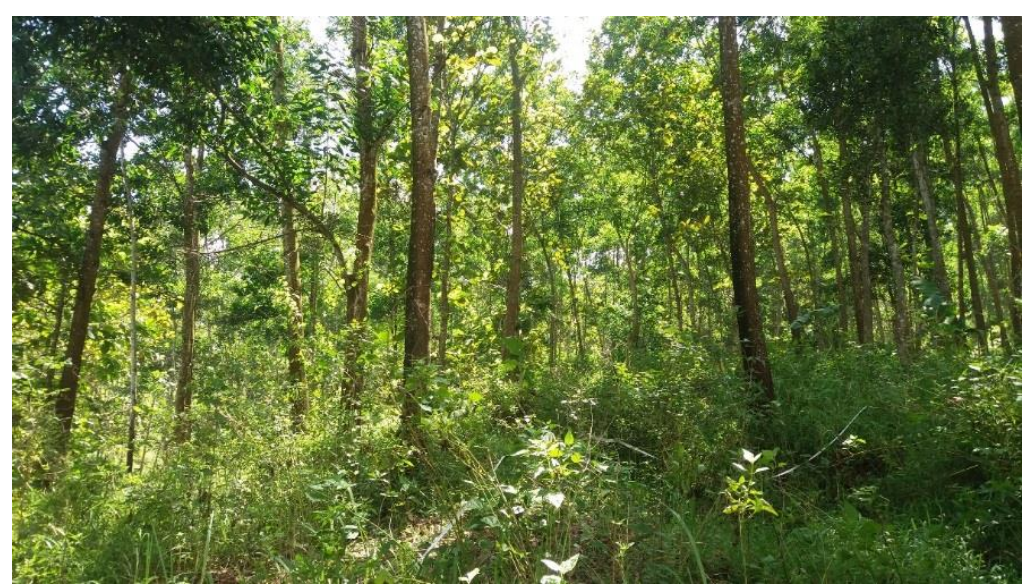

Figure 18. Acacia monoculture plantation aged 10 years

\subsubsection{Tea plantation}

The tea plantation identified (612 ha) is intensively managed by PT. Pagilaran Unit Produksi Jatilawang (Figure 19), Banjarnegara. The plantation is located in hilly areas at 740-1600 m asl and on slopes of $1-35^{\circ}$. The tea plants were spaced at $1.5 \times 1.5$ meters. Beside the plantation own by PT. Pagilaran, local farmers also cultivate tea on a small scale at a denser $(0.5 \times 0.5 \mathrm{~m})$ spacing integrated with sengon trees. Two plots of tea plantation were established with co-ordinate location at $7.264490^{\circ}$ and $109.714620^{\circ},-7.207345^{\circ}$ and $109.760306^{\circ}$.

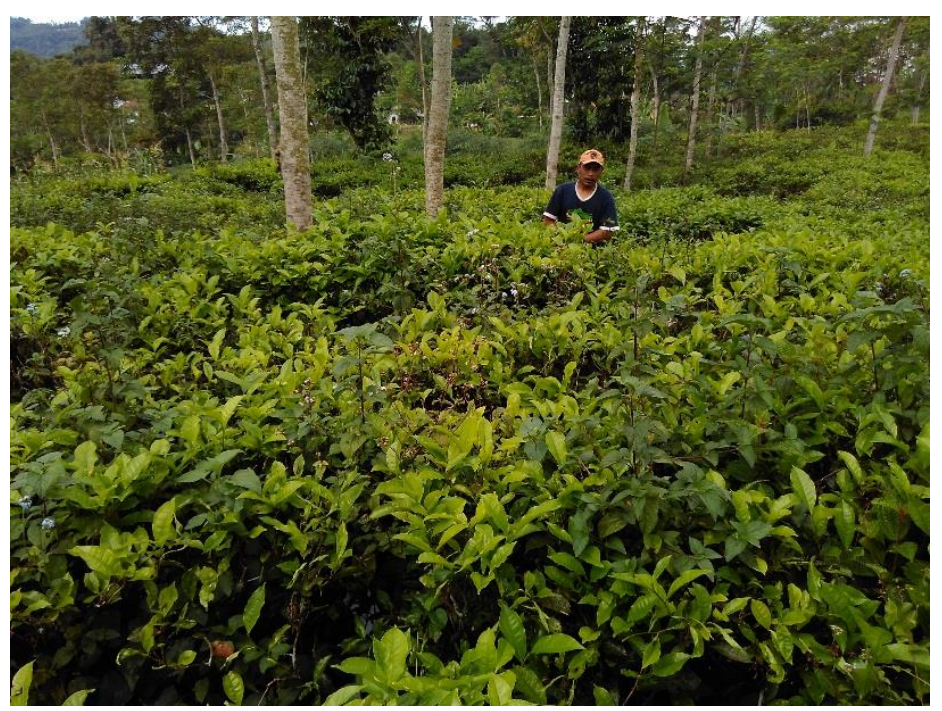

Figure 19. Tea plantation

\subsubsection{Shrub}

Shrub land is a non-tree-based land use system consisting of non-arboreal or small tree vegetation, usually less than 5-6 meters high. Sometimes abandoned land that has been occupied by pioneer vegetation is categorized as shrub land (Figure 20). Two plots of shrub land were established with coordinate location at $-7.42033^{\circ}$ and $109.19402^{\circ},-7.210085^{\circ}$ and $109.762581^{\circ}$. The sampled plots were located at different elevation in Banjarnegara is at $1394 \mathrm{~m}$ asl and in Banyumas at $81 \mathrm{~m}$ asl, respectively. 


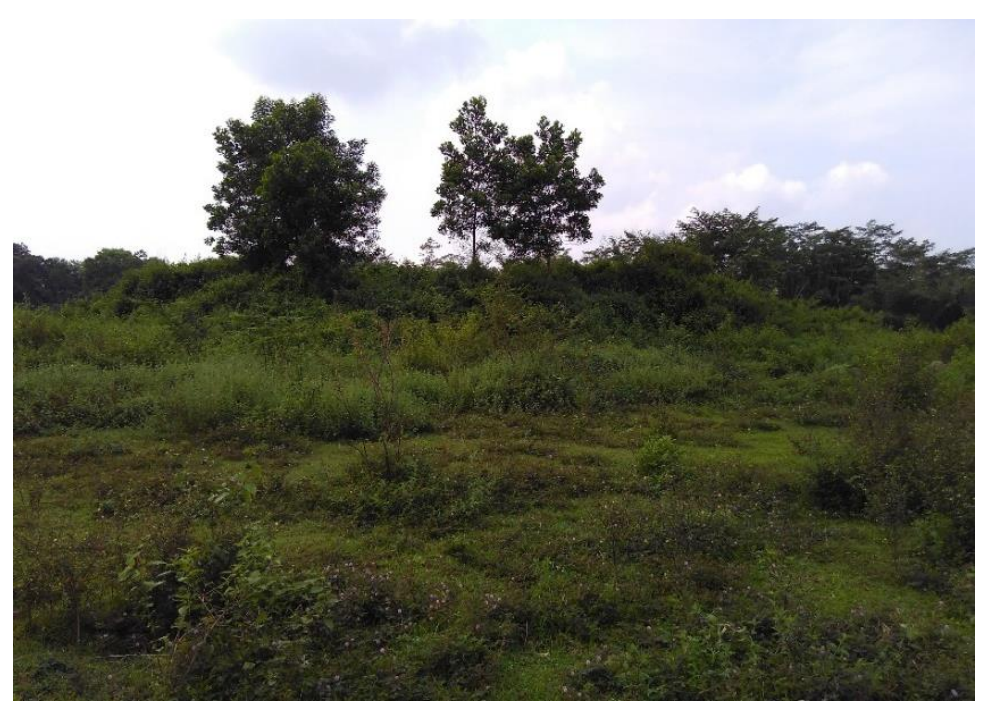

Figure 20. Shrub land

\subsection{Tree Diversity and Composition}

\subsubsection{Species Richness and Diversity}

Agroforestry types in Banyumas, Banjarnegara and Purbalingga had different characteristic regarding species richness and tree diversity (Table 3). The low intensive management of complex agroforest and duku agroforest contained the most diverse tree species that tended to be constant among growth stages. There was a relative increase from seedlings to trees in the complex agroforest. Undisturbed forest, located in mountainous areas, contained fewer tree species than the complex agroforest, duku agroforest and snake-fruit agroforest that were mostly managed by smallholder farmers.

The tree species diversity in the timber-based systems, for both agroforest and monoculture (teak and sengon) decreased dramatically from the seedling to the tree stage, due to weeding activity.

The perennial crop-based systems of cacao and coffee had very different tree species richness and diversity. The cacao agroforest managed by the private company was less divers than the coffee agroforest managed by smallholder farmers. In coffee agroforest, the tree species diversity tended to increase from the seedling to the tree stage, but the opposite occurred in cacao agroforest. Farmers usually planted other utilized species or did selected weeding for utilized species in the coffee agroforest, but the private company managed the cacao agroforest intensively, only focusing on cacao and shade-tree species.

The monoculture systems and plantations managed by companies (both state-owned and private) such as pine, agathis and tea, had low tree species richness and diversity. Tree diversity dramatically decreased from the seedling to the tree stage. 
Table 3. Species richness and diversity index for various land use systems

\begin{tabular}{lrrrrrrrr}
\hline \multirow{2}{*}{ Land use } & Number & Species & & \multicolumn{5}{c}{ Shannon-Wiener diversity index (H') } \\
\cline { 4 - 8 } & of plots & richness & Seedling & Sapling & Pole & Tree & All growth stage \\
\hline Undisturbed forest & 3 & 12 & 0 & 1.53 & 1.17 & 1.73 & 1.88 \\
Agathis plantation & 6 & 15 & 1.52 & 1.64 & 0 & 0.16 & 0.58 \\
Pines plantation & 6 & 17 & 1.71 & 0.80 & 0.64 & 0.15 & 0.47 \\
Acacia plantation & 3 & 5 & 0.63 & 0.68 & 0.48 & 0.88 & 1.16 \\
\hline Duku agroforest & 3 & 27 & 1.71 & 2.06 & 2.04 & 1.71 & 2.06 \\
Complex agroforest & 5 & 53 & 2.43 & 2.40 & 2.57 & 2.68 & 2.92 \\
Teak agroforest & 7 & 36 & 2.49 & 2.03 & 1.29 & 1.24 & 0.18 \\
Teak monoculture & 6 & 15 & 0.19 & 0 & 0 & 0 & 0.03 \\
Rubber monoculture & 11 & 4 & 1.41 & 1.29 & 0.29 & 0.15 & 1.64 \\
\hline Sengon agroforest & 7 & 26 & 1.51 & 1.36 & 0.57 & 0.33 & 0.65 \\
\hline Sengon monoculture & 6 & 8 & 1.39 & 0.15 & 0.03 & 0.15 & 0.18 \\
Cacao agroforest & 3 & 8 & 0.68 & 0 & 0 & 0.35 & 0.39 \\
Coffee agroforest & 3 & 14 & 0.51 & 0.94 & 0.94 & 0.75 & 1.40 \\
Snakefruit agroforest & 2 & 14 & 0.33 & 0.50 & 1.52 & 1.94 & 2.03 \\
\hline Tea plantation & 2 & 2 & 0 & 0 & 0 & 0 & 0.37 \\
Shrub & 2 & 4 & 0.69 & 0 & 0 & 0 & 1.04 \\
\hline
\end{tabular}

\subsubsection{Species Dominance}

The most three dominant species in the agroforestry systems in Banyumas, Banjarnegara and Purbalingga varied in the seedling, sapling, pole and tree stages (Table 4) depending on the system and management applied. A pioneer species (Ficus septica) was very common and was one of the most dominant seedling species in many land use systems. Mahogany (Swietenia macrophylla) was a common species in the seedling and sapling stages in complex systems such as complex agroforest, duku agroforest and teak agroforest. In the seedling stage, it was possible for many species to regenerate in various systems depending on the availability of seed dispersal agents and the sampling distance from the seed sources. However, management applied in the systems affected the surviving species in the higher growth stages. Intensive management may have resulted in some seedling species being lost due to weeding activities, but selective weeding may have allowed some seedling species to develop to later stages. In the coffee and cacao-based agroforest, we found that the main commodity was the dominant species in all growth stages. No seedlings were found in the tea plantation due to high density which provided no chance for most species to germinate under such a dense canopy. Intensive weeding applied in the tea plantation (usually herbicide) would have killed all competing seedling species. 
Table 4. Three most dominant species in various land use systems

\begin{tabular}{|c|c|c|c|c|}
\hline \multirow{2}{*}{$\begin{array}{l}\text { Land use } \\
\text { system }\end{array}$} & \multicolumn{4}{|c|}{ Vegetation growth stage } \\
\hline & Seedling & Sapling & Pole & Tree \\
\hline $\begin{array}{l}\text { Undisturbed } \\
\text { forest }^{1}\end{array}$ & Lithocarpus spicatus & $\begin{array}{l}\text { L. spicatus } \\
\text { Debregeasia longifolia } \\
\text { Macropanax dispermus }\end{array}$ & $\begin{array}{l}\text { L.spicatus } \\
\text { Macropanax } \\
\text { dispermus } \\
\text { Schefflera fastigiata }\end{array}$ & $\begin{array}{l}\text { M.dispermus } \\
\text { Engelhardia spicata } \\
\text { Astronia spectabilis }\end{array}$ \\
\hline $\begin{array}{l}\text { Agathis } \\
\text { plantation }\end{array}$ & $\begin{array}{l}\text { Calliandra calothyrsus } \\
\text { Agathis loranthifolia } \\
\text { Coffea canephora }\end{array}$ & $\begin{array}{l}\text { Agathis loranthifolia } \\
\text { Castanopsis argentea } \\
\text { Xanthophyllum } \\
\text { vitellinum }\end{array}$ & - & $\begin{array}{l}\text { A. loranthifolia } \\
\text { Schima wallichii } \\
\text { Eucalyptus } \\
\text { urophylla }\end{array}$ \\
\hline $\begin{array}{l}\text { Pines } \\
\text { plantation }\end{array}$ & $\begin{array}{l}\text { Ficus septica } \\
\text { Calliandra calothyrsus } \\
\text { C. canephora } \\
\end{array}$ & $\begin{array}{l}\text { F. septica } \\
\text { Gnetum gnemon } \\
\text { Hibiscus tiliaceus }\end{array}$ & $\begin{array}{l}\text { Pinus merkusii } \\
\text { Citrus aurantifolia } \\
\text { S. wallichii } \\
\end{array}$ & $\begin{array}{l}\text { P. merkusii } \\
\text { S. wallichii } \\
\text { Senna siamea }\end{array}$ \\
\hline $\begin{array}{l}\text { Acacia }^{2} \\
\text { plantation }\end{array}$ & $\begin{array}{l}\text { Pterocarpus indicus } \\
\text { Acacia auriculiformis }\end{array}$ & $\begin{array}{l}P . \text { indicus } \\
A . \text { auriculiformis }\end{array}$ & $\begin{array}{l}\text { A. auriculiformis } \\
\text { Tectona grandis }\end{array}$ & $\begin{array}{l}\text { A. auriculiformis } \\
\text { Acacia mangium } \\
\text { T. grandis }\end{array}$ \\
\hline $\begin{array}{l}\text { Duku } \\
\text { agroforest }\end{array}$ & $\begin{array}{l}\text { F. septica } \\
\text { Lansium domesticum } \\
\text { Vitex pinnata }\end{array}$ & $\begin{array}{l}\text { L. domesticum } \\
\text { Peronema canescens } \\
\text { Swietenia macrophylla }\end{array}$ & $\begin{array}{l}\text { L. domesticum } \\
\text { Albizia chinensis } \\
\text { Durio zibethinus }\end{array}$ & $\begin{array}{l}\text { L. domesticum } \\
\text { Cocos nucifera } \\
\text { A. chinensis }\end{array}$ \\
\hline $\begin{array}{l}\text { Complex } \\
\text { agroforest }\end{array}$ & $\begin{array}{l}\text { S. macrophylla } \\
\text { Buchanania } \\
\text { sessilifolia } \\
\text { Dalbergia latifolia }\end{array}$ & $\begin{array}{l}\text { S. macrophylla } \\
\text { Hibiscus tiliaceus } \\
\text { Nephelium lappaceum }\end{array}$ & $\begin{array}{l}\text { S. macrophylla } \\
\text { Theobroma cacao } \\
\text { A. chinensis }\end{array}$ & $\begin{array}{l}\text { A. chinensis } \\
\text { C. nucifera } \\
\text { S. macrophylla }\end{array}$ \\
\hline $\begin{array}{l}\text { Teak } \\
\text { agroforest }\end{array}$ & $\begin{array}{l}\text { S. macrophylla } \\
\text { F. septica } \\
\text { C. canephora }\end{array}$ & $\begin{array}{l}\text { T. grandis } \\
\text { S.macrophylla } \\
\text { C. canephora }\end{array}$ & $\begin{array}{l}\text { T. grandis } \\
\text { A. chinensis } \\
\text { A. auriculiformis }\end{array}$ & $\begin{array}{l}\text { T. grandis } \\
\text { C. nucifera } \\
\text { A. chinensis }\end{array}$ \\
\hline $\begin{array}{l}\text { Teak } \\
\text { Monoculture }\end{array}$ & $\begin{array}{l}\text { T. grandis } \\
\text { C. siamea } \\
\text { S. macrophylla }\end{array}$ & $\begin{array}{l}\text { T. grandis } \\
\text { C. siamea } \\
\text { Leucaena leucocephala }\end{array}$ & $\begin{array}{l}\text { T. grandis } \\
\text { A. auriculiformis } \\
\text { Cassia siamea }\end{array}$ & $\begin{array}{l}\text { T. grandis } \\
\text { C. nucifera } \\
\text { A. auriculiformis }\end{array}$ \\
\hline $\begin{array}{l}\text { Rubber } \\
\text { monoculture }\end{array}$ & $\begin{array}{l}\text { Hevea brasiliensis } \\
\text { N. lappaceum } \\
\text { F. septica }\end{array}$ & $\begin{array}{l}\text { H. brasiliensis } \\
\text { C. canephora } \\
\text { Gliricidia sepium }\end{array}$ & H. brasiliensis & H. brasiliensis \\
\hline $\begin{array}{l}\text { Sengon } \\
\text { agroforest }\end{array}$ & $\begin{array}{l}\text { C. canephora } \\
\text { F. septica } \\
P . \text { falcataria }\end{array}$ & $\begin{array}{l}\text { C. canephora } \\
\text { G. sepium } \\
P . \text { falcataria }\end{array}$ & $\begin{array}{l}\text { P. falcataria } \\
\text { C. canephora } \\
\text { T. grandis } \\
\end{array}$ & $\begin{array}{l}P . \text { falcataria } \\
T . \text { grandis } \\
\text { C. nucifera }\end{array}$ \\
\hline $\begin{array}{l}\text { Sengon } \\
\text { monoculture }\end{array}$ & $\begin{array}{l}P . \text { falcataria } \\
\text { F. septica } \\
\text { S. macrophylla }\end{array}$ & $\begin{array}{l}\text { P. falcataria } \\
\text { S. macrophylla }\end{array}$ & $\begin{array}{l}\text { P. falcataria } \\
\text { S. macrophylla }\end{array}$ & $\begin{array}{l}\text { P. falcataria } \\
\text { C. nucifera } \\
\text { Anthocephalus } \\
\text { cadamba }\end{array}$ \\
\hline $\begin{array}{l}\text { Cacao } \\
\text { agroforest }^{3}\end{array}$ & $\begin{array}{l}\text { F. septica } \\
\text { Theobroma cacao }\end{array}$ & T. cacao & T. cacao & $\begin{array}{l}\text { T. cacao } \\
\text { C. nucifera } \\
\text { T. grandis }\end{array}$ \\
\hline $\begin{array}{l}\text { Coffee } \\
\text { agroforest }\end{array}$ & $\begin{array}{l}\text { C. canephora } \\
\text { Camellia sinensis } \\
\text { Coffea arabica }\end{array}$ & $\begin{array}{l}\text { C. canephora } \\
\text { C. arabica } \\
\text { P. falcataria }\end{array}$ & $\begin{array}{l}\text { P. falcataria } \\
\text { C. canephora } \\
\text { Artocarpus } \\
\text { heterophyllus }\end{array}$ & $\begin{array}{l}P \text {. falcataria } \\
\text { Artocarpus } \\
\text { heterophyllus } \\
\text { Archidendron } \\
\text { fagifolium }\end{array}$ \\
\hline $\begin{array}{l}\text { Snakefruit } \\
\text { agroforest }\end{array}$ & $\begin{array}{l}\text { C. canephora } \\
\text { F. septica }\end{array}$ & - & $\begin{array}{l}\text { C. canephora } \\
\text { L. leucocephala } \\
\text { P. falcataria }\end{array}$ & $\begin{array}{l}\text { L. leucocephala } \\
\text { A. heterophyllus } \\
\text { C. nucifera }\end{array}$ \\
\hline Tea plantation ${ }^{4}$ & - & Camellia sinensis & Camellia sinensis & $\begin{array}{l}\text { Paraserianthes } \\
\text { falcataria }\end{array}$ \\
\hline Shrub $^{5}$ & $\begin{array}{l}\text { Psidium guajava } \\
\text { Eucalyptus urophylla }\end{array}$ & - & Acacia mangium & A. mangium \\
\hline
\end{tabular}

\footnotetext{
${ }^{1}$ In the undisturbed forest there are only found single species at seedling

2 In the acacia plantation there are only found two species at seedling to pole

${ }^{3}$ In the cacao agroforest there are only found two species at seedling, even single species at sapling and pole

${ }^{4}$ In the tea plantation are only found single species at sapling to tree

${ }^{5}$ In the shrub there only two species found at seedling and single species at pole and tree
} 


\subsubsection{Similarity Index Comparisons}

A similarity index determines how closely the current vegetation community resembles either the potential natural community or some other reference community. The similarity index values among the land use systems in the three districts of Banyumas, Banjarnegara and Purbalingga varied depending on the land use and growth stage comparison (Table 5). Species composition in undisturbed forest plots located at a higher elevation and categorized as mountainous forest were completely different to other land use systems. Beside the undisturbed forest, tea and acacia plantation also has a specific species composition which was completely different to the other land use systems in the area in all growth stages.

Generally, shared species occurred among agroforestry systems, but the numbers of shared species decreased in the higher level growth stages. Teak and complex agroforest had the highest number of shared species compared to the other agroforest systems indicting that the teak and complex agroforests in the area can accommodate more species to regenerate. In contrast, the monoculture systems of rubber, sengon and teak had shared species in the seedling stage, but only a few in the higher level growth stages. Weeding activities only allow tree species to regenerate but not necessarily to further develop. 
Table 5. Similarity matrix of seedling, sapling, pole and tree species among land uses systems

\begin{tabular}{|c|c|c|c|c|c|c|c|c|c|c|c|c|c|c|c|c|}
\hline Land use system & AcP & AgP & SAF & SM & CcA & CoA & DAF & $\mathrm{CmA}$ & PP & UF & RM & SH & SF & TP & TAF & TM \\
\hline \multicolumn{17}{|c|}{ Seedling } \\
\hline Acacia plantation (AcP) & & 0.00 & 0.00 & 0.00 & 0.00 & 0.00 & 0.00 & 0.00 & 0.00 & 0.00 & 0.00 & 0.00 & 0.00 & 0.00 & 0.03 & 0.05 \\
\hline Agathis plantation (AgP) & & & 0.22 & 0.00 & 0.00 & 0.20 & 0.00 & 0.07 & 0.30 & 0.00 & 0.00 & 0.00 & 0.27 & 0.00 & 0.13 & 0.00 \\
\hline Sengon agroforest (SAF) & & & & 0.34 & 0.19 & 0.46 & 0.11 & 0.17 & 0.22 & 0.00 & 0.02 & 0.00 & 0.59 & 0.00 & 0.33 & 0.09 \\
\hline Sengon monoculture (SM) & & & & & 0.44 & 0.00 & 0.23 & 0.09 & 0.20 & 0.00 & 0.02 & 0.00 & 0.10 & 0.00 & 0.13 & 0.07 \\
\hline Cacao agroforest (CcA) & & & & & & 0.00 & 0.20 & 0.02 & 0.22 & 0.00 & 0.02 & 0.00 & 0.12 & 0.00 & 0.09 & 0.04 \\
\hline Coffee agroforest (CoA) & & & & & & & 0.00 & 0.09 & 0.13 & 0.00 & 0.00 & 0.00 & 0.43 & 0.00 & 0.21 & 0.00 \\
\hline Duku agroforest (DAF) & & & & & & & & 0.10 & 0.32 & 0.00 & 0.02 & 0.04 & 0.05 & 0.00 & 0.22 & 0.08 \\
\hline Complex agroforest $(\mathrm{CmA})$ & & & & & & & & & 0.07 & 0.00 & 0.04 & 0.00 & 0.13 & 0.00 & 0.37 & 0.13 \\
\hline Pines plantation (PP) & & & & & & & & & & 0.00 & 0.02 & 0.00 & 0.20 & 0.00 & 0.23 & 0.03 \\
\hline Undisturbed forest (UF) & & & & & & & & & & & 0.00 & 0.00 & 0.00 & 0.00 & 0.00 & 0.00 \\
\hline Rubber monoculture (RM) & & & & & & & & & & & & 0.02 & 0.02 & 0.00 & 0.05 & 0.03 \\
\hline Shrub (SH) & & & & & & & & & & & & & 0.00 & 0.00 & 0.16 & 0.10 \\
\hline Snakefruit agroforest (SF) & & & & & & & & & & & & & & 0.00 & 0.21 & 0.04 \\
\hline Tea plantation (TP) & & & & & & & & & & & & & & & 0.00 & 0.00 \\
\hline Teak agroforest (TAF) & & & & & & & & & & & & & & & & 0.27 \\
\hline \multicolumn{17}{|l|}{ Teak monoculture (TM) } \\
\hline \multicolumn{17}{|c|}{ Sapling } \\
\hline Acacia plantation (AcP) & & 0.00 & 0.00 & 0.00 & 0.00 & 0.00 & 0.00 & 0.00 & 0.00 & 0.00 & 0.00 & 0.00 & 0.00 & 0.00 & 0.02 & 0.03 \\
\hline Agathis plantation (AgP) & & & 0.04 & 0.00 & 0.00 & 0.01 & 0.04 & 0.02 & 0.00 & 0.00 & 0.00 & 0.00 & 0.13 & 0.00 & 0.04 & 0.00 \\
\hline Sengon agroforest (SAF) & & & & 0.08 & 0.00 & 0.23 & 0.21 & 0.17 & 0.08 & 0.00 & 0.00 & 0.00 & 0.21 & 0.00 & 0.28 & 0.07 \\
\hline Sengon monoculture (SM) & & & & & 0.00 & 0.10 & 0.13 & 0.06 & 0.00 & 0.00 & 0.00 & 0.00 & 0.00 & 0.00 & 0.08 & 0.00 \\
\hline Cacao agroforest (CcA) & & & & & & 0.00 & 0.00 & 0.00 & 0.00 & 0.00 & 0.00 & 0.00 & 0.00 & 0.00 & 0.00 & 0.00 \\
\hline Coffee agroforest (CoA) & & & & & & & 0.06 & 0.06 & 0.00 & 0.00 & 0.00 & 0.00 & 0.05 & 0.00 & 0.07 & 0.00 \\
\hline Duku agroforest (DAF) & & & & & & & & 0.27 & 0.09 & 0.00 & 0.00 & 0.00 & 0.10 & 0.00 & 0.23 & 0.04 \\
\hline Complex agroforest $(\mathrm{CmA})$ & & & & & & & & & 0.07 & 0.00 & 0.00 & 0.00 & 0.10 & 0.00 & 0.32 & 0.11 \\
\hline
\end{tabular}




\begin{tabular}{|c|c|c|c|c|c|c|c|c|c|c|c|c|c|c|c|c|}
\hline Land use system & AcP & AgP & SAF & SM & CcA & CoA & DAF & $\mathrm{CmA}$ & PP & UF & RM & SH & SF & TP & TAF & TM \\
\hline Pines plantation (PP) & & & & & & & & & & 0.00 & 0.00 & 0.00 & 0.00 & 0.00 & 0.19 & 0.00 \\
\hline Undisturbed forest (UF) & & & & & & & & & & & 0.00 & 0.00 & 0.00 & 0.00 & 0.00 & 0.00 \\
\hline Rubber monoculture (RM) & & & & & & & & & & & & 0.00 & 0.00 & 0.00 & 0.00 & 0.00 \\
\hline Shrub (SH) & & & & & & & & & & & & & 0.00 & 0.00 & 0.00 & 0.00 \\
\hline Snakefruit agroforest (SF) & & & & & & & & & & & & & & 0.00 & 0.16 & 0.00 \\
\hline Tea plantation (TP) & & & & & & & & & & & & & & & 0.00 & 0.00 \\
\hline Teak agroforest (TAF) & & & & & & & & & & & & & & & & 0.31 \\
\hline \multicolumn{17}{|l|}{ Teak monoculture (TM) } \\
\hline \multicolumn{17}{|c|}{ Pole } \\
\hline Acacia plantation (AcP) & & 0.00 & 0.04 & 0.00 & 0.00 & 0.00 & 0.00 & 0.06 & 0.00 & 0.00 & 0.00 & 0.00 & 0.00 & 0.00 & 0.15 & 0.16 \\
\hline Agathis plantation (AgP) & & & 0.00 & 0.00 & 0.00 & 0.00 & 0.00 & 0.00 & 0.00 & 0.00 & 0.00 & 0.00 & 0.00 & 0.00 & 0.00 & 0.00 \\
\hline Sengon agroforest (SAF) & & & & 0.67 & 0.00 & 0.49 & 0.09 & 0.13 & 0.00 & 0.00 & 0.00 & 0.00 & 0.07 & 0.00 & 0.14 & 0.03 \\
\hline Sengon monoculture (SM) & & & & & 0.00 & 0.28 & 0.03 & 0.05 & 0.00 & 0.00 & 0.00 & 0.00 & 0.02 & 0.00 & 0.08 & 0.00 \\
\hline Cacao agroforest (CcA) & & & & & & 0.00 & 0.00 & 0.22 & 0.00 & 0.00 & 0.00 & 0.00 & 0.00 & 0.00 & 0.00 & 0.00 \\
\hline Coffee agroforest (CoA) & & & & & & & 0.09 & 0.10 & 0.00 & 0.00 & 0.00 & 0.00 & 0.14 & 0.00 & 0.12 & 0.00 \\
\hline Duku agroforest (DAF) & & & & & & & & 0.16 & 0.00 & 0.00 & 0.00 & 0.00 & 0.21 & 0.00 & 0.11 & 0.00 \\
\hline Complex agroforest (CmA) & & & & & & & & & 0.00 & 0.00 & 0.00 & 0.00 & 0.09 & 0.00 & 0.17 & 0.04 \\
\hline Pines plantation (PP) & & & & & & & & & & 0.00 & 0.00 & 0.00 & 0.00 & 0.00 & 0.00 & 0.00 \\
\hline Undisturbed forest (UF) & & & & & & & & & & & 0.00 & 0.00 & 0.00 & 0.00 & 0.00 & 0.00 \\
\hline Rubber monoculture (RM) & & & & & & & & & & & & 0.00 & 0.00 & 0.00 & 0.00 & 0.00 \\
\hline Shrub (SH) & & & & & & & & & & & & & 0.00 & 0.00 & 0.02 & 0.00 \\
\hline Snakefruit agroforest (SF) & & & & & & & & & & & & & & 0.00 & 0.04 & 0.00 \\
\hline Tea plantation (TP) & & & & & & & & & & & & & & & 0.00 & 0.00 \\
\hline Teak agroforest (TAF) & & & & & & & & & & & & & & & & 0.72 \\
\hline \multicolumn{17}{|l|}{ Teak monoculture (TM) } \\
\hline \multicolumn{17}{|c|}{ Tree } \\
\hline Acacia plantation (AcP) & & 0.00 & 0.02 & 0.00 & 0.02 & 0.00 & 0.00 & 0.03 & 0.00 & 0.00 & 0.00 & 0.01 & 0.00 & 0.00 & 0.06 & 0.04 \\
\hline Agathis plantation (AgP) & & & 0.00 & 0.00 & 0.00 & 0.00 & 0.00 & 0.00 & 0.02 & 0.00 & 0.00 & 0.00 & 0.00 & 0.00 & 0.00 & 0.00 \\
\hline
\end{tabular}




\begin{tabular}{|c|c|c|c|c|c|c|c|c|c|c|c|c|c|c|c|c|}
\hline Land use system & AcP & AgP & SAF & SM & CcA & CoA & DAF & $\mathrm{CmA}$ & PP & UF & RM & SH & SF & TP & TAF & TM \\
\hline Sengon agroforest (SAF) & & & & 0.86 & 0.03 & 0.26 & 0.08 & 0.27 & 0.00 & 0.00 & 0.00 & 0.00 & 0.03 & 0.08 & 0.09 & 0.03 \\
\hline Sengon monoculture (SM) & & & & & 0.01 & 0.22 & 0.05 & 0.20 & 0.00 & 0.00 & 0.00 & 0.00 & 0.02 & 0.07 & 0.05 & 0.01 \\
\hline Cacao agroforest (CcA) & & & & & & 0.01 & 0.06 & 0.06 & 0.00 & 0.00 & 0.00 & 0.01 & 0.04 & 0.01 & 0.04 & 0.02 \\
\hline Coffee agroforest (CoA) & & & & & & & 0.17 & 0.32 & 0.00 & 0.00 & 0.00 & 0.00 & 0.12 & 0.39 & 0.11 & 0.00 \\
\hline Duku agroforest (DAF) & & & & & & & & 0.24 & 0.00 & 0.00 & 0.00 & 0.00 & 0.11 & 0.16 & 0.15 & 0.02 \\
\hline Complex agroforest $(\mathrm{CmA})$ & & & & & & & & & 0.00 & 0.00 & 0.00 & 0.00 & 0.07 & 0.10 & 0.28 & 0.06 \\
\hline Pines plantation (PP) & & & & & & & & & & 0.00 & 0.00 & 0.00 & 0.00 & 0.00 & 0.00 & 0.00 \\
\hline Undisturbed forest (UF) & & & & & & & & & & & 0.00 & 0.00 & 0.00 & 0.00 & 0.00 & 0.00 \\
\hline Rubber monoculture (RM) & & & & & & & & & & & & 0.00 & 0.00 & 0.00 & 0.00 & 0.00 \\
\hline Shrub (SH) & & & & & & & & & & & & & 0.00 & 0.00 & 0.00 & 0.00 \\
\hline Snakefruit agroforest (SF) & & & & & & & & & & & & & & 0.04 & 0.09 & 0.02 \\
\hline Tea plantation (TP) & & & & & & & & & & & & & & & 0.08 & 0.00 \\
\hline Teak agroforest (TAF) & & & & & & & & & & & & & & & & 0.75 \\
\hline Teak monoculture (TM) & & & & & & & & & & & & & & & & \\
\hline
\end{tabular}




\subsection{Above-ground Carbon Stock}

Slow-growing, timber-based agroforest, complex agroforest and duku agroforest as germplasm conservation areas contained about $60 \%$ of the carbon stock in the undisturbed forest, but twice as much as the fast-growing, timber-based systems of acacia and sengon (Table 6).

Table 6. Above-ground carbon stock of various land use systems

\begin{tabular}{lcrrrrrrr}
\hline \multirow{2}{*}{ Land use system } & \multirow{2}{*}{$\begin{array}{c}\text { Number } \\
\text { of plots }\end{array}$} & \multicolumn{7}{c}{ Above-ground carbon stock (Mg ha ${ }^{-1}$ ) } \\
\cline { 3 - 9 } & Tree & Necromass & Understorey & Litter & Frond & Stalk & Total \\
\hline Undisturbed forest & 1 & 162.7 & 7.3 & 3.9 & 8.5 & - & - & 182.4 \\
Agathis plantation & 6 & 110.1 & 0.6 & 2.3 & 4.5 & - & - & 117.5 \\
Pines plantation & 6 & 80.9 & 0.1 & 0.7 & 1.0 & - & - & 82.8 \\
Acacia plantation & 3 & 48.0 & 0 & 0 & 0 & - & - & 48.0 \\
Duku agroforest & 3 & 84.0 & 0 & 0.2 & 1.1 & - & - & 85.3 \\
Complex agroforest & 5 & 77.6 & 0.4 & 0.2 & 1.6 & - & - & 79.8 \\
Teak agroforest & 7 & 69.8 & 0.1 & 0.5 & 0.6 & - & - & 71.0 \\
Teak monoculture & 6 & 60.5 & 0 & 0.5 & 0.8 & - & - & 61.7 \\
Rubber monoculture & 9 & 49.6 & 0.1 & 0.5 & 0.5 & - & - & 50.7 \\
Sengon agroforest & 7 & 43.1 & 0 & 0.5 & 0.7 & - & - & 44.4 \\
Sengon monoculture & 6 & 39.6 & 0.1 & 1.6 & 0.5 & - & - & 41.8 \\
Cacao agroforest & 3 & 33.8 & 0.5 & 1.7 & 2.4 & - & - & 38.3 \\
Coffee agroforest & 3 & 24.3 & 0.1 & 0.4 & 1.2 & - & - & 26.0 \\
Snakefruit agroforest & 2 & 6.6 & 0 & 0.2 & 0.6 & 10.03 & 1.28 & 18.7 \\
Tea plantation & 2 & 17.7 & 0.1 & 1.2 & 1.1 & - & - & 20.1 \\
Shrub & 2 & 2.5 & 0 & 3.3 & 0.1 & - & - & 5.9 \\
\hline
\end{tabular}

\section{Conclusions}

Higher tree species richness and diversity were found in the complex systems of the complex agroforest, duku agroforest and teak agroforest which were low intensively managed. High species richness and tree diversity under medium and intensive management such as for timber plantations and crop-based agroforestry managed by companies (both state-owned and private) only occurred in the seedling stage. Weeding activity had a high impact resulting in tree species being lost from systems. Wild pioneer species were commonly found as a dominant species in any land use system in the seedling stage. No tree species common among land use systems were found in undisturbed forest, acacia and teak monoculture plantation. Complex systems and slow-growing, timber-based systems contained greater carbon stock than fast-growing, timber-based and crop-based systems. 


\section{References}

Chave J, Andalo C, Brown S, Cairns MA, Chambers JQ, et al. 2005. Tree allometry and improved estimation of carbon stocks and balance in tropical forests. Oecologia 145:87-99. DOI 10.1007/s00442-005-0100-x.

Colwell RK. 2009. Biodiversity: Concepts, Patterns and Measurement. In Simon A. L. The Princeton Guide to Ecology. Princeton: Princeton University Press. pp. 257-263.

Curtis JT, McIntosh RP. 1950. The interrelations of certain analytic and synthetic phytosociological characters. Ecology 31: 434-455.

Hairiah K, Dewi S, Agus F, Velarde S, Ekadinata A, et al. 2011. Measuring Carbon Stocks Across Land Use Systems: A Manual. Bogor, Indonesia: World Agroforestry Centre (ICRAF), SEA Regional Office, 154 pp. 



\section{WORKING PAPERS WITH DOIs}

2005

1. Agroforestry in the drylands of eastern Africa: a call to action

2. Biodiversity conservation through agroforestry: managing tree species diversity within a network of community-based, nongovernmental, governmental and research organizations in western Kenya.

3. Invasion of prosopis juliflora and local livelihoods: Case study from the Lake Baringo area of Kenya

4. Leadership for change in farmers organizations: Training report: Ridar Hotel, Kampala, 29th March to 2nd April 2005.

5. Domestication des espèces agroforestières au Sahel : situation actuelle et perspectives

6. Relevé des données de biodiversité ligneuse: Manuel du projet biodiversité des parcs agroforestiers au Sahel

7. Improved land management in the Lake Victoria Basin: TransVic Project's draft report.

8. Livelihood capital, strategies and outcomes in the Taita hills of Kenya

9. Les espèces ligneuses et leurs usages: Les préférences des paysans dans le Cercle de Ségou, au Mali

10. La biodiversité des espèces ligneuses: Diversité arborée et unités de gestion du terroir dans le Cercle de Ségou, au Mali

\section{6}

11. Bird diversity and land use on the slopes of Mt. Kilimanjaro and the adjacent plains, Tanzania

12. Water, women and local social organization in the Western Kenya Highlands

13. Highlights of ongoing research of the World Agroforestry Centre in Indonesia

14. Prospects of adoption of tree-based systems in a rural landscape and its likely impacts on carbon stocks and farmers' welfare: The FALLOW Model Application in Muara Sungkai, Lampung, Sumatra, in a 'Clean Development Mechanism' context

15. Equipping integrated natural resource managers for healthy Agroforestry landscapes.

17. Agro-biodiversity and CGIAR tree and forest science: approaches and examples from Sumatra.

18. Improving land management in eastern and southern Africa: A review of policies.

19. Farm and household economic study of Kecamatan Nanggung, Kabupaten Bogor, Indonesia: A socio-economic base line study of Agroforestry innovations and livelihood enhancement.

20. Lessons from eastern Africa's unsustainable charcoal business.

21. Evolution of RELMA's approaches to land management: Lessons from two decades of research and development in eastern and southern Africa

22. Participatory watershed management: Lessons from RELMA's work with farmers in eastern Africa.

23. Strengthening farmers' organizations: The experience of RELMA and ULAMP.

24. Promoting rainwater harvesting in eastern and southern Africa.

25. The role of livestock in integrated land management.

26. Status of carbon sequestration projects in Africa: Potential benefits and challenges to scaling up. 
27. Social and Environmental Trade-Offs in Tree Species Selection: A Methodology for Identifying Niche Incompatibilities in Agroforestry [Appears as AHI Working Paper no. 9]

28. Managing tradeoffs in agroforestry: From conflict to collaboration in natural resource management. [Appears as AHI Working Paper no. 10]

29. Essai d'analyse de la prise en compte des systemes agroforestiers pa les legislations forestieres au Sahel: Cas du Burkina Faso, du Mali, du Niger et du Senegal.

30. Etat de la recherche agroforestière au Rwanda etude bibliographique, période 1987-2003

2007

31. Science and technological innovations for improving soil fertility and management in Africa: A report for NEPAD's Science and Technology Forum.

32. Compensation and rewards for environmental services.

33. Latin American regional workshop report compensation.

34. Asia regional workshop on compensation ecosystem services.

35. Report of African regional workshop on compensation ecosystem services.

36. Exploring the inter-linkages among and between compensation and rewards for ecosystem services CRES and human well-being

37. Criteria and indicators for environmental service compensation and reward mechanisms: realistic, voluntary, conditional and pro-poor

38. The conditions for effective mechanisms of compensation and rewards for environmental services.

39. Organization and governance for fostering Pro-Poor Compensation for Environmental Services.

40. How important are different types of compensation and reward mechanisms shaping poverty and ecosystem services across Africa, Asia \& Latin America over the Next two decades?

41. Risk mitigation in contract farming: The case of poultry, cotton, woodfuel and cereals in East Africa.

42. The RELMA savings and credit experiences: Sowing the seed of sustainability

43. Yatich J., Policy and institutional context for NRM in Kenya: Challenges and opportunities for Landcare.

44. Nina-Nina Adoung Nasional di So! Field test of rapid land tenure assessment (RATA) in the Batang Toru Watershed, North Sumatera.

45. Is Hutan Tanaman Rakyat a new paradigm in community based tree planting in Indonesia?

46. Socio-Economic aspects of brackish water aquaculture (Tambak) production in Nanggroe Aceh Darrusalam.

47. Farmer livelihoods in the humid forest and moist savannah zones of Cameroon.

48. Domestication, genre et vulnérabilité : Participation des femmes, des Jeunes et des catégories les plus pauvres à la domestication des arbres agroforestiers au Cameroun.

49. Land tenure and management in the districts around Mt Elgon: An assessment presented to the Mt Elgon ecosystem conservation programme.

50. The production and marketing of leaf meal from fodder shrubs in Tanga, Tanzania: A pro-poor enterprise for improving livestock productivity.

51. Buyers Perspective on Environmental Services (ES) and Commoditization as an approach to liberate ES markets in the Philippines. 
52. Towards Towards community-driven conservation in southwest China: Reconciling state and local perceptions.

53. Biofuels in China: An Analysis of the Opportunities and Challenges of Jatropha curcas in Southwest China.

54. Jatropha curcas biodiesel production in Kenya: Economics and potential value chain development for smallholder farmers

55. Livelihoods and Forest Resources in Aceh and Nias for a Sustainable Forest Resource Management and Economic Progress

56. Agroforestry on the interface of Orangutan Conservation and Sustainable Livelihoods in Batang Toru, North Sumatra.

2008

57. Assessing Hydrological Situation of Kapuas Hulu Basin, Kapuas Hulu Regency, West Kalimantan.

58. Assessing the Hydrological Situation of Talau Watershed, Belu Regency, East Nusa Tenggara.

59. Kajian Kondisi Hidrologis DAS Talau, Kabupaten Belu, Nusa Tenggara Timur.

60. Kajian Kondisi Hidrologis DAS Kapuas Hulu, Kabupaten Kapuas Hulu, Kalimantan Barat.

61. Lessons learned from community capacity building activities to support agroforest as sustainable economic alternatives in Batang Toru orang utan habitat conservation program (Martini, Endri et al.)

62. Mainstreaming Climate Change in the Philippines.

63. A Conjoint Analysis of Farmer Preferences for Community Forestry Contracts in the Sumber Jaya Watershed, Indonesia.

64. The highlands: a shared water tower in a changing climate and changing Asia

65. Eco-Certification: Can It Deliver Conservation and Development in the Tropics.

66. Designing ecological and biodiversity sampling strategies. Towards mainstreaming climate change in grassland management.

67. Towards mainstreaming climate change in grassland management policies and practices on the Tibetan Plateau

68. An Assessment of the Potential for Carbon Finance in Rangelands

69 ECA Trade-offs Among Ecosystem Services in the Lake Victoria Basin.

69. The last remnants of mega biodiversity in West Java and Banten: an in-depth exploration of RaTA (Rapid Land Tenure Assessment) in Mount Halimun-Salak National Park Indonesia

70. Le business plan d'une petite entreprise rurale de production et de commercialisation des plants des arbres locaux. Cas de quatre pépinières rurales au Cameroun.

71. Les unités de transformation des produits forestiers non ligneux alimentaires au Cameroun. Diagnostic technique et stratégie de développement Honoré Tabuna et Ingratia Kayitavu.

72. Les exportateurs camerounais de safou (Dacryodes edulis) sur le marché sous régional et international. Profil, fonctionnement et stratégies de développement.

73. Impact of the Southeast Asian Network for Agroforestry Education (SEANAFE) on agroforestry education capacity.

74. Setting landscape conservation targets and promoting them through compatible land use in the Philippines.

75. Review of methods for researching multistrata systems. 
76. Study on economical viability of Jatropha curcas L. plantations in Northern Tanzania assessing farmers' prospects via cost-benefit analysis

77. Cooperation in Agroforestry between Ministry of Forestry of Indonesia and International Center for Research in Agroforestry

78. "China's bioenergy future. an analysis through the Lens if Yunnan Province

79. Land tenure and agricultural productivity in Africa: A comparative analysis of the economics literature and recent policy strategies and reforms

80. Boundary organizations, objects and agents: linking knowledge with action in Agroforestry watersheds

81. Reducing emissions from deforestation and forest degradation (REDD) in Indonesia: options and challenges for fair and efficient payment distribution mechanisms

2009

82. Mainstreaming climate change into agricultural education: challenges and perspectives

83. Challenging conventional mindsets and disconnects in conservation: the emerging role of ecoagriculture in Kenya's landscape mosaics

84. Lesson learned RATA garut dan bengkunat: suatu upaya membedah kebijakan pelepasan kawasan hutan dan redistribusi tanah bekas kawasan hutan

85. The emergence of forest land redistribution in Indonesia

86. Commercial opportunities for fruit in Malawi

87. Status of fruit production processing and marketing in Malawi

88. Fraud in tree science

89. Trees on farm: analysis of global extent and geographical patterns of agroforestry

90. The springs of Nyando: water, social organization and livelihoods in Western Kenya

91. Building capacity toward region-wide curriculum and teaching materials development in agroforestry education in Southeast Asia

92. Overview of biomass energy technology in rural Yunnan (Chinese - English abstract)

93. A pro-growth pathway for reducing net GHG emissions in China

94. Analysis of local livelihoods from past to present in the central Kalimantan Ex-Mega Rice Project area

95. Constraints and options to enhancing production of high quality feeds in dairy production in Kenya, Uganda and Rwanda

2010

96. Agroforestry education in the Philippines: status report from the Southeast Asian Network for Agroforestry Education (SEANAFE)

97. Economic viability of Jatropha curcas L. plantations in Northern Tanzania- assessing farmers' prospects via cost-benefit analysis.

98. Hot spot of emission and confusion: land tenure insecurity, contested policies and competing claims in the central Kalimantan Ex-Mega Rice Project area

99. Agroforestry competences and human resources needs in the Philippines

100. CES/COS/CIS paradigms for compensation and rewards to enhance environmental Services 
101. Case study approach to region-wide curriculum and teaching materials development in agroforestry education in Southeast Asia

102. Stewardship agreement to reduce emissions from deforestation and degradation (REDD): Lubuk Beringin's Hutan Desa as the first village forest in Indonesia

103. Landscape dynamics over time and space from ecological perspective

104. Komoditisasi atau koinvestasi jasa lingkungan: skema imbal jasa lingkungan program peduli sungai di DAS Way Besai, Lampung, Indonesia

105. Improving smallholders' rubber quality in Lubuk Beringin, Bungo district, Jambi province, Indonesia: an initial analysis of the financial and social benefits

106. Rapid Carbon Stock Appraisal (RACSA) in Kalahan, Nueva Vizcaya, Philippines

107. Tree domestication by ICRAF and partners in the Peruvian Amazon: lessons learned and future prospects in the domain of the Amazon Initiative eco-regional program

108. Memorias del Taller Nacional: "Iniciativas para Reducir la Deforestación en la region Andino Amazónica”, 09 de Abril del 2010. Proyecto REALU Peru

109. Percepciones sobre la Equidad y Eficiencia en la cadena de valor de REDD en Perú -Reporte de Talleres en Ucayali, San Martín y Loreto, 2009. Proyecto REALU-Perú.

110. Reducción de emisiones de todos los Usos del Suelo. Reporte del Proyecto REALU Perú Fase 1

111. Programa Alternativas a la Tumba-y-Quema (ASB) en el Perú. Informe Resumen y Síntesis de la Fase II. 2da. versión revisada

112. Estudio de las cadenas de abastecimiento de germoplasma forestal en la amazonía Boliviana

113. Biodiesel in the Amazon

114. Estudio de mercado de semillas forestales en la amazonía Colombiana

115. Estudio de las cadenas de abastecimiento de germoplasma forestal en Ecuador http://dx.doi.org10.5716/WP10340.PDF

116. How can systems thinking, social capital and social network analysis help programs achieve impact at scale?

117. Energy policies, forests and local communities in the Ucayali Region, Peruvian Amazon

118. NTFPs as a Source of Livelihood Diversification for Local Communities in the Batang Toru Orangutan Conservation Program

119. Studi Biodiversitas: Apakah agroforestry mampu mengkonservasi keanekaragaman hayati di DAS Konto?

120. Estimasi Karbon Tersimpan di Lahan-lahan Pertanian di DAS Konto, Jawa Timur

121. Implementasi Kaji Cepat Hidrologi (RHA) di Hulu DAS Brantas, Jawa Timur. http://dx.doi.org/10.5716/WP10338.PDF

122. Kaji Cepat Hidrologi di Daerah Aliran Sungai Krueng Peusangan, NAD,Sumatra http://dx.doi.org/10.5716/WP10337.PDF

123. A Study of Rapid Hydrological Appraisal in the Krueng Peusangan Watershed, NAD, Sumatra. http://dx.doi.org/10.5716/WP10339.PDF

2011

124. An Assessment of farm timber value chains in Mt Kenya area, Kenya

125. A Comparative financial analysis of current land use systems and implications for the adoption of improved agroforestry in the East Usambaras, Tanzania

126. Agricultural monitoring and evaluation systems 
127. Challenges and opportunities for collaborative landscape governance in the East Usambara Mountains, Tanzania

128. Transforming Knowledge to Enhance Integrated Natural Resource Management Research, Development and Advocacy in the Highlands of Eastern Africa http://dx.doi.org/10.5716/WP11084.PDF

129. Carbon-forestry projects in the Philippines: potential and challenges The Mt Kitanglad Range forest-carbon development http://dx.doi.org10.5716/WP11054.PDF

130. Carbon forestry projects in the Philippines: potential and challenges. The Arakan Forest Corridor forest-carbon project. http://dx.doi.org10.5716/WP11055.PDF

131. Carbon-forestry projects in the Philippines: potential and challenges. The Laguna Lake Development Authority's forest-carbon development project. http://dx.doi.org/10.5716/WP11056.PDF

132. Carbon-forestry projects in the Philippines: potential and challenges. The Quirino forest-carbon development project in Sierra Madre Biodiversity Corridor http://dx.doi.org10.5716/WP11057.PDF

133. Carbon-forestry projects in the Philippines: potential and challenges. The Ikalahan Ancestral Domain forest-carbon development http://dx.doi.org10.5716/WP11058.PDF

134. The Importance of Local Traditional Institutions in the Management of Natural Resources in the Highlands of Eastern Africa. http://dx.doi.org/10.5716/WP11085.PDF

135. Socio-economic assessment of irrigation pilot projects in Rwanda. http://dx.doi.org/10.5716/WP11086.PDF

136. Performance of three rambutan varieties (Nephelium lappaceum L.) on various nursery media. http://dx.doi.org/10.5716/WP11232.PDF

137. Climate change adaptation and social protection in agroforestry systems: enhancing adaptive capacity and minimizing risk of drought in Zambia and Honduras http://dx.doi.org/10.5716/WP11269.PDF

138. Does value chain development contribute to rural poverty reduction? Evidence of asset building by smallholder coffee producers in Nicaragua http://dx.doi.org/10.5716/WP11271.PDF

139. Potential for biofuel feedstock in Kenya. http://dx.doi.org/10.5716/WP11272.PDF

140. Impact of fertilizer trees on maize production and food security in six districts of Malawi. http://dx.doi.org/10.5716/WP11281.PDF

2012

141. Fortalecimiento de capacidades para la gestión del Santuario Nacional Pampa Hermosa: Construyendo las bases para un manejo adaptativo para el desarrollo local. Memorias del Proyecto. http://dx.doi.org/10.5716/WP12005.PDF

142. Understanding rural institutional strengthening: A cross-level policy and institutional framework for sustainable development in Kenya http://dx.doi.org/10.5716/WP12012.PDF

143. Climate change vulnerability of agroforestry http://dx.doi.org/10.5716/WP16722.PDF

144. Rapid assesment of the inner Niger delta of Mali http://dx.doi.org/10.5716/WP12021.PDF

145. Designing an incentive program to reduce on-farm deforestationin the East Usambara Mountains, Tanzania http://dx.doi.org/10.5716/WP12048.PDF

146. Extent of adoption of conservation agriculture and agroforestry in Africa: the case of Tanzania, Kenya, Ghana, and Zambia http://dx.doi.org/10.5716/WP12049.PDF 
147. Policy incentives for scaling up conservation agriculture with trees in Africa: the case of Tanzania, Kenya, Ghana and Zambia http://dx.doi.org/10.5716/WP12050.PDF

148. Commoditized or co-invested environmental services? Rewards for environmental services scheme: River Care program Way Besai watershed, Lampung, Indonesia. http://dx.doi.org/10.5716/WP12051.PDF

149. Assessment of the headwaters of the Blue Nile in Ethiopia. http://dx.doi.org/10.5716/WP12160.PDF

150. Assessment of the uThukela Watershed, Kwazaulu. http://dx.doi.org/10.5716/WP12161.PDF

151. Assessment of the Oum Zessar Watershed of Tunisia. http://dx.doi.org/10.5716/WP12162.PDF

152. Assessment of the Ruwenzori Mountains in Uganda. http://dx.doi.org/10.5716/WP12163.PDF

153. History of agroforestry research and development in Viet Nam. Analysis of research opportunities and gaps. http://dx.doi.org/10.5716/WP12052.PDF

154. REDD+ in Indonesia: a Historical Perspective. http://dx.doi.org/10.5716/WP12053.PDF

155. Agroforestry and Forestry in Sulawesi series: Livelihood strategies and land use system dynamics in South Sulawesi http://dx.doi.org/10.5716/WP12054.PDF

156. Agroforestry and Forestry in Sulawesi series: Livelihood strategies and land use system dynamics in Southeast Sulawesi. http://dx.doi.org/10.5716/WP12055.PDF

157. Agroforestry and Forestry in Sulawesi series: Profitability and land-use systems in South and Southeast Sulawesi. http://dx.doi.org/10.5716/WP12056.PDF

158. Agroforestry and Forestry in Sulawesi series: Gender, livelihoods and land in South and Southeast Sulawesi http://dx.doi.org/10.5716/WP12057.PDF

159. Agroforestry and Forestry in Sulawesi series: Agroforestry extension needs at the community level in AgFor project sites in South and Southeast Sulawesi, Indonesia. http://dx.doi.org/10.5716/WP12058.PDF

160. Agroforestry and Forestry in Sulawesi series: Rapid market appraisal of agricultural, plantation and forestry commodities in South and Southeast Sulawesi. http://dx.doi.org/10.5716/WP12059.PDF

2013

161. Diagnosis of farming systems in the Agroforestry for Livelihoods of Smallholder farmers in Northwestern Viet Nam project http://dx.doi.org/10.5716/WP13033.PDF

162. Ecosystem vulnerability to climate change: a literature review. http://dx.doi.org/10.5716/WP13034.PDF

163. Local capacity for implementing payments for environmental services schemes: lessons from the RUPES project in northeastern Viet Nam http://dx.doi.org/10.5716/WP13046.PDF

164. Seri Agroforestri dan Kehutanan di Sulawesi: Agroforestry dan Kehutanan di Sulawesi: Strategi mata pencaharian dan dinamika sistem penggunaan lahan di Sulawesi Selatan http://dx.doi.org/10.5716/WP13040.PDF

165. Seri Agroforestri dan Kehutanan di Sulawesi: Mata pencaharian dan dinamika sistem penggunaan lahan di Sulawesi Tenggara http://dx.doi.org/10.5716/WP13041.PDF

166. Seri Agroforestri dan Kehutanan di Sulawesi: Profitabilitas sistem penggunaan lahan di Sulawesi Selatan dan Sulawesi Tenggara http://dx.doi.org/10.5716/WP13042.PDF

167. Seri Agroforestri dan Kehutanan di Sulawesi: Gender, mata pencarian dan lahan di Sulawesi Selatan dan Sulawesi Tenggara http://dx.doi.org/10.5716/WP13043.PDF 
168. Seri Agroforestri dan Kehutanan di Sulawesi: Kebutuhan penyuluhan agroforestri pada tingkat masyarakat di lokasi proyek AgFor di Sulawesi Selatan dan Tenggara, Indonesia. http://dx.doi.org/10.5716/WP13044.PDF

169. Seri Agroforestri dan Kehutanan di Sulawesi: Laporan hasil penilaian cepat untuk komoditas pertanian, perkebunan dan kehutanan di Sulawesi Selatan dan Tenggara http://dx.doi.org/10.5716/WP13045.PDF

170. Agroforestry, food and nutritional security http://dx.doi.org/10.5716/WP13054.PDF

171. Stakeholder Preferences over Rewards for Ecosystem Services: Implications for a REDD+ Benefit Distribution System in Viet Nam http://dx.doi.org/10.5716/WP13057.PDF

172. Payments for ecosystem services schemes: project-level insights on benefits for ecosystems and the rural poor http://dx.doi.org/10.5716/WP13001.PDF

173. Good practices for smallholder teak plantations: keys to success http://dx.doi.org/10.5716/WP13246.PDF

174. Market analysis of selected agroforestry products in the Vision for Change Project intervention Zone, Côte d'Ivoire http://dx.doi.org/10.5716/WP13249.PDF

175. Rattan futures in Katingan: why do smallholders abandon or keep their gardens in Indonesia's 'rattan district'? http://dx.doi.org/10.5716/WP13251.PDF

176. Management along a gradient: the case of Southeast Sulawesi's cacao production landscapes http://dx.doi.org/10.5716/WP13265.PDF

2014

177. Are trees buffering ecosystems and livelihoods in agricultural landscapes of the Lower Mekong Basin? Consequences for climate-change adaptation. http://dx.doi.org/10.5716/WP14047.PDF

178. Agroforestry, livestock, fodder production and climate change adaptation and mitigation in East Africa: issues and options. http://dx.doi.org/10.5716/WP14050.PDF

179. Trees on farms: an update and reanalysis of agroforestry's global extent and socio-ecological characteristics. http://dx.doi.org/10.5716/WP14064.PDF

180. Beyond reforestation: an assessment of Vietnam's REDD+ readiness. http://dx.doi.org/10.5716/WP14097.PDF

181. Farmer-to-farmer extension in Kenya: the perspectives of organizations using the approach. http://dx.doi.org/10.5716/WP14380.PDF

182. Farmer-to-farmer extension in Cameroon: a survey of extension organizations. http://dx.doi.org/10.5716/WP14383.PDF

183. Farmer-to-farmer extension approach in Malawi: a survey of organizations: a survey of organizations http://dx.doi.org/10.5716/WP14391.PDF

184. Seri Agroforestri dan Kehutanan di Sulawesi: Kuantifikasi jasa lingkungan air dan karbon pola agroforestri pada hutan rakyat di wilayah sungai Jeneberang

185. Options for Climate-Smart Agriculture at Kaptumo Site in Kenyahttp://dx.doi.org/10.5716/WP14394.PDF

2015

186. Agroforestry for Landscape Restoration and Livelihood Development in Central Asia http://dx.doi.org/10.5716/WP14143.PDF 
187. "Projected Climate Change and Impact on Bioclimatic Conditions in the Central and SouthCentral Asia Region" http://dx.doi.org/10.5716/WP14144.PDF

188. Land Cover Changes, Forest Loss and Degradation in Kutai Barat, Indonesia. http://dx.doi.org/10.5716/WP14145.PDF

189. The Farmer-to-Farmer Extension Approach in Malawi: A Survey of Lead Farmers. http://dx.doi.org/10.5716/WP14152.PDF

190. Evaluating indicators of land degradation and targeting agroforestry interventions in smallholder farming systems in Ethiopia. http://dx.doi.org/10.5716/WP14252.PDF

191. Land health surveillance for identifying land constraints and targeting land management options in smallholder farming systems in Western Cameroon

192. Land health surveillance in four agroecologies in Malawi

193. Cocoa Land Health Surveillance: an evidence-based approach to sustainable management of cocoa landscapes in the Nawa region, South-West Côte d'Ivoire http://dx.doi.org/10.5716/WP14255.PDF

194. Situational analysis report: Xishuangbanna autonomous Dai Prefecture, Yunnan Province, China. http://dx.doi.org/10.5716/WP14255.PDF

195. Farmer-to-farmer extension: a survey of lead farmers in Cameroon. http://dx.doi.org/10.5716/WP15009.PDF

196. From transition fuel to viable energy source Improving sustainability in the sub-Saharan charcoal sector http://dx.doi.org/10.5716/WP15011.PDF

197. Mobilizing Hybrid Knowledge for More Effective Water Governance in the Asian Highlands http://dx.doi.org/10.5716/WP15012.PDF

198. Water Governance in the Asian Highlands http://dx.doi.org/10.5716/WP15013.PDF

199. Assessing the Effectiveness of the Volunteer Farmer Trainer Approach in Dissemination of Livestock Feed Technologies in Kenya vis-à-vis other Information Sources http://dx.doi.org/10.5716/WP15022.PDF

200. The rooted pedon in a dynamic multifunctional landscape: Soil science at the World Agroforestry Centre http://dx.doi.org/10.5716/WP15023.PDF

201. Characterising agro-ecological zones with local knowledge. Case study: Huong Khe district, $\mathrm{Ha}$ Tinh, Viet Nam http://dx.doi.org/10.5716/WP15050.PDF

202. Looking back to look ahead: Insight into the effectiveness and efficiency of selected advisory approaches in the dissemination of agricultural technologies indicative of Conservation Agriculture with Trees in Machakos County, Kenya. http://dx.doi.org/10.5716/WP15065.PDF

203. Pro-poor Biocarbon Projects in Eastern Africa Economic and Institutional Lessons. http://dx.doi.org/10.5716/WP15022.PDF

204. Projected climate change impacts on climatic suitability and geographical distribution of banana and coffee plantations in Nepal. http://dx.doi.org/10.5716/WP15294.PDF

205. Agroforestry and Forestry in Sulawesi series: Smallholders' coffee production and marketing in Indonesia. A case study of two villages in South Sulawesi Province. http://dx.doi.org/10.5716/WP15690.PDF

206. Mobile phone ownership and use of short message service by farmer trainers: a case study of Olkalou and Kaptumo in Kenya http://dx.doi.org/10.5716/WP15691.PDF

207. Associating multivariate climatic descriptors with cereal yields: a case study of Southern Burkina Faso http://dx.doi.org/10.5716/WP15273.PDF

208. Preferences and adoption of livestock feed practices among farmers in dairy management groups in Kenya http://dx.doi.org/10.5716/WP15675.PDF 
209. Scaling up climate-smart agriculture: lessons learned from South Asia and pathways for success http://dx.doi.org/10.5716/WP15720.PDF

210. Agroforestry and Forestry in Sulawesi series: Local perceptions of forest ecosystem services and collaborative formulation of reward mechanisms in South and Southeast Sulawesi http://dx.doi.org/10.5716/WP15721.PDF

211. Potential and challenges in implementing the co-investment of ecosystem services scheme in Buol District, Indonesia. http://dx.doi.org/10.5716/WP15722.PDF

212. Tree diversity and its utilization by the local community in Buol District, Indonesia http://dx.doi.org/10.5716/WP15723.PDF

213 Vulnerability of smallholder farmers and their preferences on farming practices in Buol District, Indonesia http://dx.doi.org/10.5716/WP15724.PDF

214. Dynamics of Land Use/Cover Change and Carbon Emission in Buol District, Indonesia http://dx.doi.org/10.5716/WP15725.PDF

215. Gender perspective in smallholder farming practices in Lantapan, Phillippines. http://dx.doi.org/10.5716/WP15726.PDF

216. Vulnerability of smallholder farmers in Lantapan, Bukidnon. http://dx.doi.org/10.5716/WP15727.PDF

217. Vulnerability and adaptive capacity of smallholder farmers in Ho Ho Sub-watershed, Ha Tinh Province, Vietnam http://dx.doi.org/10.5716/WP15728.PDF

218. Local Knowledge on the role of trees to enhance livelihoods and ecosystem services in northern central Vietnam http://dx.doi.org/10.5716/WP15729.PDF

219. Land-use/cover change in Ho Ho Sub-watershed, Ha Tinh Province, Vietnam. http://dx.doi.org/10.5716/WP15730.PDF

2016

220. Agroforestry and Forestry in Sulawesi series: Evaluation of the Agroforestry Farmer Field Schools on agroforestry management in South and Southeast Sulawesi, Indonesia. http://dx.doi.org/10.5716/WP16002.PDF

221. Farmer-to-farmer extension of livestock feed technologies in Rwanda: A survey of volunteer farmer trainers and organizations. http://dx.doi.org/10.5716/WP16005.PDF

222. Projected Climate Change Impact on Hydrology, Bioclimatic Conditions, and Terrestrial Ecosystems in the Asian Highlands http://dx.doi.org/10.5716/WP16006.PDF

223. Adoption of Agroforestry and its impact on household food security among farmers in Malawi http://dx.doi.org/10.5716/WP16013.PDF

224. Agroforestry and Forestry in Sulawesi series: Information channels for disseminating innovative agroforestry practices to villages in Southern Sulawesi, Indonesia http://dx.doi.org/10.5716/WP16034.PDF

225. Agroforestry and Forestry in Sulawesi series: Unravelling rural migration networks.Landtenure arrangements among Bugis migrant communities in Southeast Sulawesi. http://dx.doi.org/10.5716/WP16035.PDF

226. Agroforestry and Forestry in Sulawesi series: Women's participation in agroforestry: more benefit or burden? A gendered analysis of Gorontalo Province. http://dx.doi.org/10.5716/WP16036.PDF

227. Kajian Kelayakan dan Pengembangan Desain Teknis Rehabilitasi Pesisir di Sulawesi Tengah. http://dx.doi.org/10.5716/WP16037.PDF

228. Selection of son tra clones in North West Vietnam. http://dx.doi.org/10.5716/WP16038.PDF 
229. Growth and fruit yield of seedlings, cuttings and grafts from selected son tra trees in Northwest Vietnam http://dx.doi.org/10.5716/WP16046.PDF

230. Gender-Focused Analysis of Poverty and Vulnerability in Yunnan, China http://dx.doi.org/10.5716/WP16071.PDF

231. Seri Agroforestri dan Kehutanan di Sulawesi: Kebutuhan Penyuluhan Agroforestri untuk Rehabilitasi Lahan di Sumba Timur, Nusa Tenggara Timur, Indonesia. http://dx.doi.org/10.5716/WP16077.PDF

232. Agroforestry and Forestry in Sulawesi series: Agroforestry extension needs for land rehabilitation in East Sumba, East Nusa Tenggara, Indonesia. http://dx.doi.org/10.5716/WP16078.PDF

233. Central hypotheses for the third agroforestry paradigm within a common definition. http://dx.doi.org/10.5716/WP16079.PDF

234. Assessing smallholder farmers' interest in shade coffee trees: The Farming Systems of Smallholder Coffee Producers in the Gisenyi Area, Rwanda: a participatory diagnostic study. http://dx.doi.org/10.5716/WP16104.PDF

235. Review of agricultural market information systems in /sub-Saharan Africa. http://dx.doi.org/10.5716/WP16110.PDF

236. Vision and road map for establishment of a protected area in Lag Badana, Lower Jubba, Somalia. http://dx.doi.org/10.5716/WP16127.PDF

237. Replicable tools and frameworks for Bio-Carbon Development in West Africa. http://dx.doi.org/10.5716/WP16138.PDF

238. Existing Conditions, Challenges and Needs in the Implementation of Forestry and Agroforestry Extension in Indonesia. http://dx.doi.org/10.5716/WP16141.PDF

239. Situasi Terkini, Tantangan dan Kebutuhan Pelaksanaan Penyuluhan Kehutanan dan Agroforestri di Indonesia. http://dx.doi.org/10.5716/WP16142.PDF

240. The national agroforestry policy of India: experiential learning in development and delivery phases. http://dx.doi.org/10.5716/WP16143.PDF

241. Agroforestry and Forestry in Sulawesi series: Livelihood strategies and land-use system dynamics in Gorontalo. http://dx.doi.org/10.5716/WP16157.PDF

242. Seri Agroforestri dan Kehutanan di Sulawesi: Strategi mata pencaharian dan dinamika sistem penggunaan lahan di Gorontalo. http://dx.doi.org/10.5716/WP16158.PDF

243. Ruang, Gender dan Kualitas Hidup Manusia: Sebuah studi Gender pada komunitas perantau dan pengelola kebun di Jawa Barat. http://dx.doi.org/10.5716/WP16159.PDF

244. Gendered Knowledge and perception in managing grassland areas in East Sumba, Indonesia. http://dx.doi.org/10.5716/WP16160.PDF

245. Pengetahuan dan persepsi masyarakat pengelola padang aavana, Sebuah Kajian Gender di Sumba Timur. http://dx.doi.org/10.5716/WP16161.PDF

246. Dinamika Pengambilan Keputusan pada komunitas perantau dan pengelola kebun di Jawa Barat. http://dx.doi.org/10.5716/WP16162.PDF

247. Gaharu (eaglewood) domestication: Biotechnology, markets and agroforestry options. http://dx.doi.org/10.5716/WP16163.PDF

248. Marine habitats of the Lamu-Kiunga coast: an assessment of biodiversity value, threats and opportunities. http://dx.doi.org/10.5716/WP16167.PDF

249. Assessment of the biodiversity in terrestrial landscapes of the Witu protected area and surroundings, Lamu County Kenya. http://dx.doi.org/10.5716/WP16172.PDF

250. An ecosystem services perspective on benefits that people derive from biodiversity of Coastal forests in Lamu County, Kenya http://dx.doi.org/10.5716/WP16173.PDF 
251. Assessment of the biodiversity in terrestrial and marine landscapes of the proposed Laga Badana National Park and surrounding areas, Jubaland, Somalia.

http://dx.doi.org/10.5716/WP16174.PDF

2017

252. Preferensi Petani terhadap Topik Penyuluhan dan Penyebaran Informasi Agroforestri di Indonesia. http://dx.doi.org/10.5716/WP16181.PDF

253. Seri Agroforestri dan Kehutanan di Sulawesi: Keanekaragaman hayati jenis pohon pada hutan rakyat agroforestri di DAS Balangtieng, Sulawesi Selatan. http://dx.doi.org/10.5716/WP16182.PDF

254. Potensi dan Tantangan dalam Pengembangan Skema Ko-Investasi Jasa Lingkungan di Kabupaten Buol, Indonesia. http://dx.doi.org/10.5716/WP17008.PDF

255. Keragaman Jenis Pohon dan Pemanfaatannya oleh Masyarakat di Kabupaten Buol, Indonesia. http://dx.doi.org/10.5716/WP17009.PDF

256. Kerentanan dan preferensi sistem pertanian petani di Kabupaten Buol, Indonesia. http://dx.doi.org/10.5716/WP17010.PDF

257. Dinamika Perubahan Penggunaan/Tutupan Lahan Serta Cadangan Karbon di Kabupaten Buol, Indonesia. http://dx.doi.org/10.5716/WP17011.PDF

258. The Effectiveness of the Volunteer Farmer Trainer Approach vis-à-vis Other Information Sources in Dissemination of Livestock Feed Technologies in Uganda. http://dx.doi.org/10.5716/WP17104.PDF

259. Agroforestry and Forestry in Sulawesi series: Impact of agricultural-extension booklets on community livelihoods in South and Southeast Sulawesi. http://dx.doi.org/10.5716/WP17125.PDF

260. Petani Menjadi Penyuluh, Mungkinkah? Sebuah Pendekatan Penyuluhan dari Petani ke Petani di Kabupaten Sumba Timur. http://dx.doi.org/10.5716/WP17145.PDF

261. Dampak Perubahan Tutupan Lahan terhadap Kondisi Hidrologi di Das Buol, Kabupaten Buol, Sulawesi Tengah: Simulasi dengan Model Genriver. http://dx.doi.org/10.5716/WP17146.PDF

262. Analisis Tapak Mata Air Umbulan, Pasuruan, Jawa Timur. Kajian elemen biofisik dan persepsi masyarakat. http://dx.doi.org/10.5716/WP17147.PDF

263. Planned comparisons demystified. http://dx.doi.org/10.5716/WP17354.PDF

264. Soil health decision support for NERC digital soil platforms: A survey report. http://dx.doi.org/10.5716/WP17355.PDF

265. Seri Pembangunan Ekonomi Pedesaan Indonesia: Menanam di bukit gundul: Pengetahuan masyarakat lokal dalam upaya restorasi lahan di Sumba

Timur. http://dx.doi.org/10.5716/WP17356.PDF

266. Tree diversity and carbon stock in three districts of Kutai Timur, Pasir and Berau, East Kalimantan http://dx.doi.org/10.5716/WP17357.PDF

267. Tree Diversity and Carbon Stock in Various Land Use Systems of Banyuasin and Musi Banyuasin Districts, South Sumatera http://dx.doi.org/10.5716/WP17358.PDF

268. Tree diversity and carbon stock in various land cover systems of Jayapura, Jayawijaya and Merauke Districts, Papua Province http://dx.doi.org/10.5716/WP17359.PDF

269. Modelling tree production based on farmers' knowledge: case for kapok (Ceiba pentandra) and candlenut (Aleurites mollucana) under various agroforestry scenarios.

http://dx.doi.org/10.5716/WP17361.PDF 
270. The Impact of Land Cover and Climate Change on Present and Future Watershed Condition. Study case: Tugasan, Alanib and Kulasihan Sub-watershed of Manupali Watershed, Lantapan, Bukidnon, Philippines. http://dx.doi.org/10.5716/WP17362.PDF

271. Tree Diversity and Above-ground Carbon Stock estimation in Various Land use Systems in Banjarnegara, Banyumas and Purbalingga, Central Java.

http://dx.doi.org/10.5716/WP17363.PDF 


The World Agroforestry Centre is an autonomous, non-profit research organization whose vision is a rural transformation in the developing world as smallholder households increase their use of trees in agricultural landscapes to improve food security, nutrition, income, health, shelter, social cohesion, energy resources and environmental sustainability. The Centre generates science-based knowledge about the diverse roles that trees play in agricultural landscapes, and uses its research to advance policies and practices, and their implementation that benefit the poor and the environment. It aims to ensure that all this is achieved by enhancing the quality of its science work, increasing operational efficiency, building and maintaining strong partnerships, accelerating the use and impact of its research, and promoting greater cohesion, interdependence and alignment within the organization.

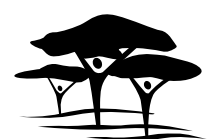

United Nations Avenue, Gigiri • PO Box 30677 • Nairobi, $00100 \cdot$ Kenya Telephone: +254 207224000 or via USA +1 6508336645 Fax: +254207224001 or via USA +1 6508336646

Email: worldagroforestry@cgiar.org•www.worldagroforestry.org

Southeast Asia Regional Program • Sindang Barang • Bogor 16680

PO Box $161 \cdot$ Bogor $16001 \cdot$ Indonesia

Telephone: +62 2518625415 • Fax: +62 2518625416

- Email: icraf-indonesia@cgiar.org

www.worldagroforestry.org/region/southeast-asia

blog.worldagroforestry.org 